\title{
Realizing Suspended Structures on Chips Fabricated by CMOS Foundry Processes Through the MOSIS Service
}

\author{
J. Marshall, M. Gaitan, M. Zaghloul, and D. Novotny \\ and \\ V. Tyree, J.-I. Pi, C. Piñá, and W. Hansford
}

U.S. Department of Commerce 



\title{
Realizing Suspended Structures on Chips Fabricated by CMOS Foundry Processes Through the MOSIS Service
}

\author{
J. Marshall, M. Gaitan, M. Zaghloul, ${ }^{*}$ and D. Novotny
}

Semiconductor Electronics Division

Electronics and Electrical Engineering Laboratory

National Institute of Standards and Technology

Gaithersburg, MD 20899

*School of Engineering and Applied Science

George Washington University

Washington, DC 20052

and

V. Tyree, J.-I. Pi, C. Piñáa, and W. Hansford

Information Sciences Institute

University of Southern California

Marina del Rey, CA 90292

June 1994

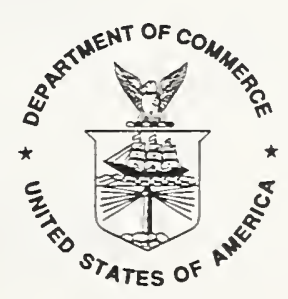

U.S. DEPARTMENT OF COMMERCE

Ronald H. Brown, Secretary

TECHNOLOGY ADMINISTRATION

Mary L. Good, Under Secretary for

Technology

NATIONAL INSTITUTE OF STANDARDS

AND TECHNOLOGY

Arati Prabhakar, Director 


\section{TABLE OF CONTENTS}

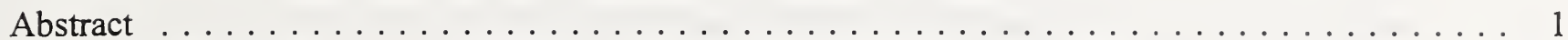

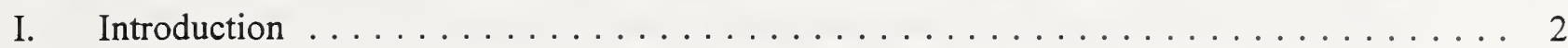

II. Design Theory . . . . . . . . . . . . . . . . . . . . . 3

A. The Resulting Cavity for a Single Open Tile $\ldots \ldots \ldots \ldots \ldots \ldots \ldots \ldots$

B. The Resulting Cavity for Multiple Open Tiles $\ldots \ldots \ldots \ldots \ldots \ldots \ldots \ldots$

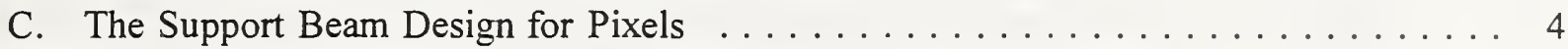

D. The Lateral Etch Stop . . . . . . . . . . . . . . . . . . . . . . 4

III. MEMS Cell Library $\ldots \ldots \ldots \ldots \ldots \ldots \ldots \ldots \ldots \ldots \ldots \ldots \ldots \ldots \ldots$

IV. Design Implementations and Recommendations $\ldots \ldots \ldots \ldots \ldots \ldots \ldots \ldots$

A. Structures to Include in the Design to Facilitate Etching $\ldots \ldots \ldots \ldots \ldots \ldots$

B. Design File Layers in the Open Tile . . . . . . . . . . . . . . . . 7

C. Design File Layers in the Pstop Tile $\ldots \ldots \ldots \ldots \ldots \ldots \ldots \ldots \ldots$

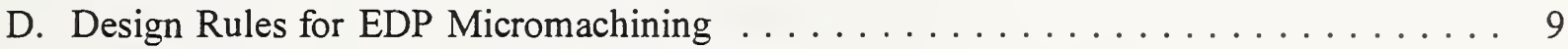

i. Design Rules for the Open Tile . . . . . . . . . . . . . . . . . . . . 9

ii. Design Rules for the Pstop Tile . . . . . . . . . . . . . . . . . . 10

V. The Etchant ............................. 10

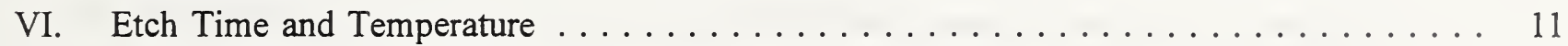

VII. The Hazards and Precautions Associated with the EDP Etchant . . . . . . . . . . . . 11

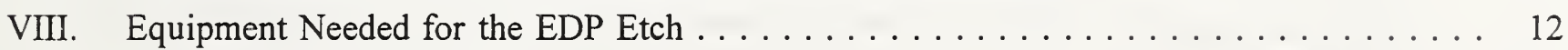

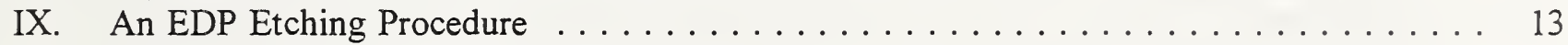

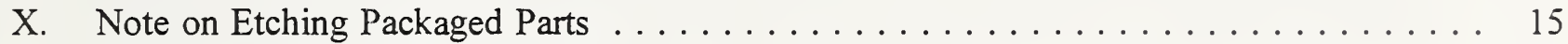

XI. For Further Information . . . . . . . . . . . . . . . . . . . . . . . . . 15

A. Health and Safety Information ........................ 15

B. General Information, Technology Files, and the MEMS Library . . . . . . . . . . 15

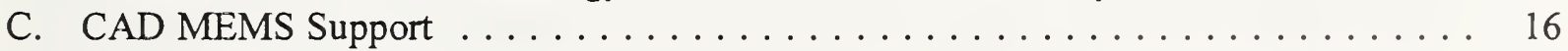

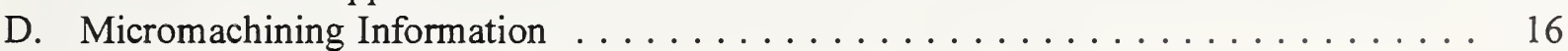

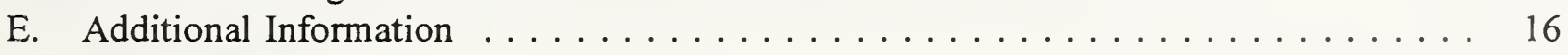

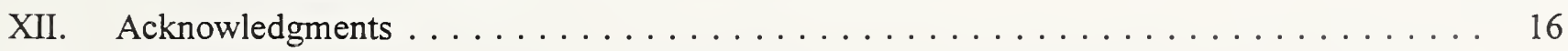

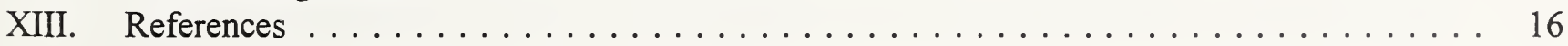

Appendix A. The MSDS for the Substance Ethylenediamine . . . . . . . . . . . . . 32

Appendix B. The MSDS for the Substance Catechol . . . . . . . . . . . . . . . . . . . 43

Appendix C. The MSDS for the Substance Pyrazine . . . . . . . . . . . . . . . . 51

\section{LIST OF FIGURES}

1. Top view of an inverted pyramid . . . . . . . . . . . . . . . . . 19

2. Top view of an inverted pyramidal-shaped trench . . . . . . . . . . . . . . . . 19

3. Four trapezoidal open tiles used to design a pixel with a trampoline-like suspended oxide in the center held up by four support beams which are also suspended . . . . . . . . 20

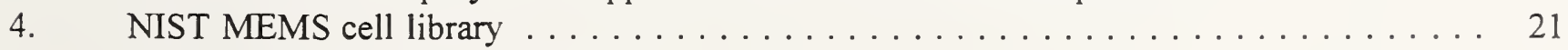

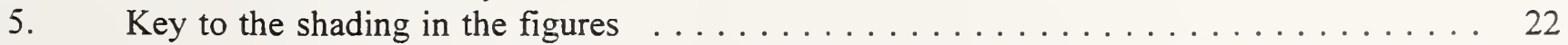


6. MEMS test structure with cell name 'open-80x80' used to check the progress of the EDP

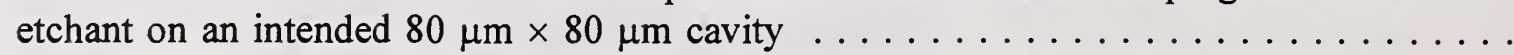

7. MEMS test structure with cell name 'open-oxide- $80 \times 80$ ' used to check the progress of the EDP etchant on an intended $80 \mu \mathrm{m} \times 80 \mu \mathrm{m}$ cavity with a trampoline-like suspended

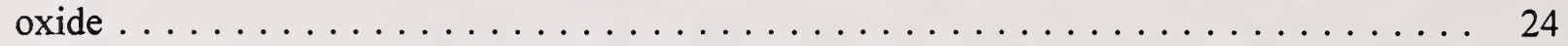

8. MEMS test structure with cell name 'thermal-converter' used as an ac power sensor . . . 25

9. MEMS test structure with cell name 'thermal-actuator' used to exhibit thermal responses

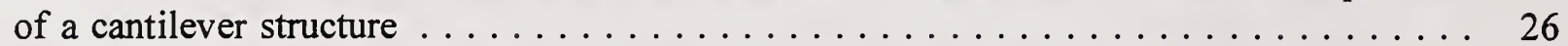

10. MEMS test structure with cell name 'pixel-80x80' used as a heating element with an

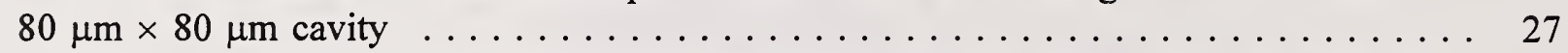

11. MEMS test structure with cell name 'pixel-160x160' used as a heating element with a

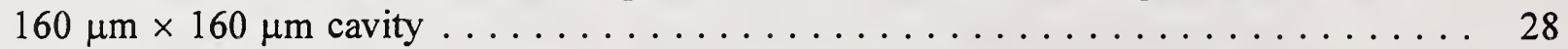

12. MEMS test structure with cell name 'micro-hot-plate' used as a microhotplate . . . . . . 29

13. MEMS test structure with cell name 'gas-sensor' used as a gas sensor . . . . . . . . . . 30

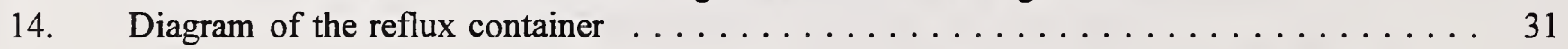

\section{LIST OF TABLES}

1. CIF Names and Calma Numbers Associated with the Design File Layers Included in the

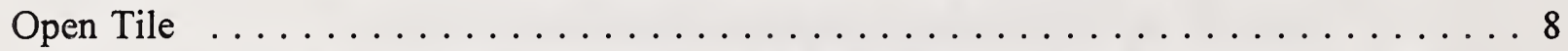

2. CIF Names and Calma Numbers Associated with the Design File Layers Included in the Pstop Tile . . . . . . . . . . . . . . . . . . . . . 9 


\title{
REALIZING SUSPENDED STRUCTURES ON CHIPS FABRICATED BY CMOS FOUNDRY PROCESSES THROUGH THE MOSIS SERVICE
}

\author{
Janet Marshall, Michael Gaitan, Mona Zaghloul,* Donald Novotny \\ Semiconductor Electronics Division \\ National Institute of Standards and Technology \\ Gaithersburg, MD 20899 \\ School of Engineering and Applied Science* \\ George Washington University \\ Washington, DC 20052 \\ and \\ Vance Tyree, Jen-I Pi, Cesar Piñá, and Wes Hansford \\ Information Sciences Institute \\ University of Southern California \\ Marina del Rey, CA 90292
}

\begin{abstract}
Chips can be inexpensively fabricated at Complementary Metal-Oxide-Semiconductor (CMOS) foundries through the MOSIS (MOSIS is an acronym for 'MOS Implementation System') Service at the University of Southern California's Information Sciences Institute. MOSIS now supports CMOS-compatible micromachining to realize microelectromechanical systems (MEMS) and devices such as suspended corners, cantilevers, and pixels. The MEMS designs are fabricated through MOSIS on a multi-project wafer, and the user performs a post-processing maskless anisotropic etch. Two new design tiles called 'open' and 'pstop' have been added to support these designs.
\end{abstract}

Key words: design rules; EDP; Magic; MEMS; micromachining; MOSIS; open tile; $p$ stop tile 


\title{
REALIZING SUSPENDED STRUCTURES ON CHIPS FABRICATED BY CMOS FOUNDRY PROCESSES THROUGH THE MOSIS SERVICE
}

\author{
Janet Marshall, Michael Gaitan, Mona Zaghloul,* Donald Novotny \\ Semiconductor Electronics Division \\ National Institute of Standards and Technology \\ School of Engineering and Applied Science* \\ George Washington University \\ Vance Tyree, Jen-I Pi, Cesar Piñá, and Wes Hansford \\ Information Sciences Institute \\ University of Southern California
}

\begin{abstract}
*** HEALTH WARNING *** THE PROCEDURES DESCRIBED BELOW REQUIRE THE USE OF CHEMICALS THAT CAN BE DANGEROUS. ONLY EXPERIENCED PERSONS WHO HAVE READ AND UNDERSTOOD ALL THE WARNINGS PROVIDED IN THIS ENTIRE TEXT SHOULD WORK WITH THESE CHEMICALS; IT IS NOT RECOMMENDED THAT STUDENTS WORK WITH THESE CHEMICALS. THE USERS ARE RESPONSIBLE FOR IMPLEMENTING THE PRECAUTIONS CONTAINED HEREIN. THIS IS A HAZARDOUS ACTIVITY TO BE UNDERTAKEN AT THE USER'S OWN RISK AND WITH AT LEAST ONE OTHER RESPONSIBLE PERSON PRESENT.
\end{abstract}

The National Institute of Standards and Technology, the Information Sciences Institute, the George Washington University, and Occupational Health Services, Inc., make no warranty as to the accuracy of the following text.

The text below identifies a commercial product and source to specify the process. This identification does not imply recommendation or endorsement, nor does it imply that the identified product and source are the best or only available product and source that can be used to produce successful devices.

Under the provisions of Section 105 of Title 17 of the United States Code, this document is not subject to copyright in the United States.

\section{INTRODUCTION}

MOSIS now supports CMOS-compatible micromachining to realize microelectromechanical systems (MEMS) and devices such as suspended corners, cantilevers, and pixels [1]. Excluding the post-processing maskless anisotropic etch, MEMS designs are fabricated through MOSIS through the normal process flow. Designs have been successfully tested on the 2- $\mu \mathrm{m}$ double poly-Scalable CMOS $N$-well Analog (SCNA) and Scalable CMOS $P$-well Electrode (SCPE) Orbit processes and will be confirmed on the other processing runs. When submitting a MEMS chip design, the user must specify the technology with the extension '_MEMS' (e.g., SCNA_MEMS).

To support these designs, two new design tiles called 'open' and 'pstop' are used. A design tile (or tile) is a digitized $\mathrm{CAD}$ construct which consists of design file layers typically corresponding to the mask(s) on which the digitized data appear. Including the open tile in the design has the effect of exposing the silicon surface to a selected ambient after fabrication through MOSIS. When the chips are delivered, a post-processing etch is performed. This etches the exposed silicon surface anisotropically to realize the 
suspended structures. Including the pstop tile in the design helps to confine the etched region. For successful designs, the placement of these tiles is crucial, as discussed in Sections II and IV.

The user must perform the post-processing etch. This text, which includes etching instructions using the chemical etchant ethylenediamine-pyrocatechol water (EDP), is included with the chips received from MOSIS along with the associated hazards and precautions associated with this etchant. These health and safety data are in the form of three Material Safety Data Sheets (MSDSs) supplied by Occupational Health Services, Inc. in Appendices A through $C$ for the substances ethylenediamine, catechol (of which pyrocatechol is a synonym), and pyrazine, which comprise the EDP referenced in this work.

\section{DESIGN THEORY}

When designing micromachined devices, there are four basic design concepts:

1. The resulting cavity for a single open tile,

2. The resulting cavity for multiple open tiles,

3. The support beam design for pixels, and

4. The lateral etch stop.

With these concepts, the design layout of any structure, either simple or complex, can be achieved with CMOS-compatible micromachining techniques, as discussed next.

\section{A. The Resulting Cavity for a Single Open Tile}

The resulting cavity for a single open tile depends upon its alignment with respect to the $x-y$ crystallographic axes. The rule for predicting the shape of the resulting cavity is:

Rule \#1 - The resulting cavity for a single open tile takes the shape of an inverted pyramid (or pyramidal-shaped trench) with a base being the smallest aligned square (or rectangle) which can enclose the vertices of the defined geometry.

The following conditions of this rule exist:

1. If the open tile is square and aligned with the crystallographic axes, then the resulting cavity is an inverted pyramid with the designed open square as its base (see fig. 1).

2. If the open tile is rectangular and aligned with the crystallographic axes, then the resulting cavity is an inverted pyramidal-shaped trench with the designed open rectangle as its base (see fig. 2).

3. If the open tile is defined with a geometry other than a square or a rectangle (e.g., a triangle or a trapezoid) and/or with a misalignment with respect to the crystallographic axes, then (as the rule implies) the resulting cavity is an inverted pyramid (or pyramidal-shaped trench) which has a square or rectangular base which is aligned with respect to the crystallographic axes and is the smallest square or rectangle that can enclose the vertices of the defined geometry.

\section{B. The Resulting Cavity for Multiple Open Tiles}

The above rule applies to one open tile. For two or more open tiles defined in close proximity, the rule 
for a single open tile is expanded and includes a determination of whether the cavities resulting from the individual open tiles merge or remain distinct. First, apply the rule for one open tile to draw the smallest enclosing rectangle around each individual tile. If none of these enclosing rectangles touch or intersect, then the two cavities remain distinct and are defined by the rule for a single open tile. If any of the enclosing rectangles touch or intersect, then during the anisotropic etch, the cavities defined by these enclosing rectangles merge to produce an inverted pyramid or pyramidal-shaped trench with a base which is the smallest, aligned square or rectangle which encloses all the vertices of the individual open tiles which have intersecting enclosing rectangles. Therefore, the resulting cavity rule for multiple open tiles (which can also be applied to a single open tile) is:

\section{Rule \#2 - The resulting cavity takes the shape of an inverted pyramid (or pyramidal-shaped trench) with a base being the smallest, aligned square (or rectangle) which can enclose the vertices of the defined geometry(ies), assuming the enclosing rectangles for the individual geometries intersect in the case of multiple geometries.}

\section{The Support Beam Design for Pixels}

Pixels look like a trampoline with the suspended region in the center held up by support beams which are also suspended. As shown in figure 3, the support beams are designed by specifying four trapezoidal open tiles for the cavity definition whose oblique edges form the edges of the support beams at an angle (generally $45^{\circ}$ ) with respect to the $x-y$ axes of the CAD layout. (The formation of these angular edges is discussed below.) A proper design produces intersecting enclosing rectangles and, after the anisotropic etch, one large inverted pyramid (or pyramidal-shaped trench) with a base being the smallest, aligned square (or rectangle) which can enclose the vertices of the defined geometries is formed.

With some CAD design tools, a smooth trapezoid can be specified. These design tools are not limited to those with 'Manhattan geometry,' which require edges that are parallel or perpendicular to the $x-y$ axes of the CAD layout, but permit trapezoidal edges.

Alternatively, with $\mathrm{CAD}$ tools limited to Manhattan geometry, many small staircase-like steps can be used to implement the oblique edges for the trapezoids that help to define the support beam edges. One-micrometer steps can be designed rapidly using automated commands on many CAD design tools. Mechanical failure may result if the support beam edges are designed with several irregular, stagger steps. If the staircase-like steps are designed with submicrometer dimensions equivalent to the step-and-repeat distance of the E-beam writer, then the trapezoidal design and the staircase design are equivalent. However, using submicrometer dimensions with some $\mathrm{CAD}$ design tools can be time-consuming.

\section{The Lateral Etch Stop}

With commercial CMOS-compatible micromachining, microstructures and support circuitry can coexist on the same substrate. The post-processing EDP etch can be prevented from proceeding towards the circuit area by precisely monitoring etch rates and times. The lateral etch stop technique (using the $p$ stop design tile) addresses this concern. The technique is very effective and reduces the need to have precise etch control.

A heavily doped boron $\left(p^{+}\right)$region in silicon can act as an etch stop during anisotropic etching. This phenomenon is the basis of the lateral etch stop in CMOS-compatible micromachining. Boron implantation is a necessary step in the standard CMOS process sequence since it is normally used to form the source/drain regions of $P$-channel Metal-Oxide-Semiconductor (PMOS) devices. Thus, the $p$ stop tile requires the active area mask (which prevents oxide from being grown on the substrate for a successful, 
subsequent implantation) and the slightly oversized $p^{+}$implant mask used in the standard process.

Considering an isolated open tile, this $p$ stop technique is effective only if the $p$ stop tile is designed parallel to its neighboring open edge and if that edge is parallel or perpendicular to the primary wafer flat which is aligned with the crystallographic axes. Otherwise, because of the undercutting nature of anisotropic etchants, the $p$ stop technique is ineffective. For the case of multiple open tiles with intersecting enclosing rectangles, the final resulting cavity can be predicted using the resulting cavity rule for multiple open tiles. The edges of this final resulting cavity are parallel or perpendicular to the primary wafer flat. The effective $p$ stop tile is designed surrounding the perimeter of this final resulting cavity. In summary, the rule for the placement of the $p$ stop tile is:

Rule \#3 - Completely surround, if possible, the perimeter of the predicted, final resulting cavity with the pstop tile.

A typical pstop tile is $5 \mu \mathrm{m}$ in width.

For the structures given in the MEMS cell library in Section III, the $p$ stop tile is missing at select corners of the predicted cavities to minimize possible transistor action. Eliminating the pstop tile at these corners does not cause a problem during the post-processing etch.

For the safety of normal CMOS operation, the pstop tile should be biased to ground (or the lowest potential on the chip) to avoid any $p n$-junction conduction.

\section{MEMS CELL LIBRARY}

The NIST MEMS cell library is shown in figure 4 with the key to the shading given in figure 5. The shading in these figures is not accurate and may mislead the reader. The figures are intended to give the reader an overall idea of what is being described. For a color representation, the authors suggest that the MEMS cell library be obtained by the method described in Section XI. The following are the cell names and cell descriptions of the individual designs which are obtainable through MOSIS.

1. open- $80 \times 80$ (shown in fig. 6)

A MEMS test structure to check the progress of the EDP etchant on an intended $80 \mu \mathrm{m} \times 80 \mu \mathrm{m}$ cavity. This design consists of a single open tile.

2. open-oxide- $80 \times 80$ (shown in fig. 7)

An additional MEMS test structure to check the progress of the etchant on an intended $80 \mu \mathrm{m}$ $\times 80 \mu \mathrm{m}$ cavity with a trampoline-like suspended oxide. This design consists of four trapezoidal-shaped open tiles brought together in close proximity such that the four cavities merge in the post-processing etch step creating one large $80 \mu \mathrm{m} \times 80 \mu \mathrm{m}$ cavity with a suspended layer of oxide (see fig. 3).

3. thermal-converter (shown in fig. 8)

A polysilicon (poly1) heater with a metall/polyl thermopile used as an ac power sensor.

4. thermal-actuator (shown in fig. 9) 
A cantilever structure consisting of polyl with metall on top. These are connected at the end of the 'diving board,' and when heated, the diving board bends upward due to the different thermal expansion coefficients of polyl and metall.

5. pixel-80x80 (shown in fig. 10)

A heating element with an $80 \mu \mathrm{m} \times 80 \mu \mathrm{m}$ cavity. The heating element is made of meandering polysilicon (poly1) and is suspended over top of the cavity with its encompassing oxide after the anisotropic etch.

6. pixel-160x160 (shown in fig. 11)

Similar to the above structure but with a $160 \mu \mathrm{m} \times 160 \mu \mathrm{m}$ cavity.

7. micro-hot-plate (shown in fig. 12)

The microhotplate design in the cell named micro-hot-plate consists of:

a. A meandering polysilicon (poly1) heating element with two external connections.

b. An aluminum (metall) plate with four external connections over top of the polysilicon (poly1) heating element. There is an oxide separating the polyl and metall. The heat is uniformly distributed across this metall plate with the metall resistance changing linearly with temperature. The metall sheet resistance at the various temperatures can be obtained with a van der Pauw measurement.

8. gas-sensor (shown in fig. 13)

The gas sensor design consists of the microhotplate design above with the addition of two layers:

a. Four metal2 pads placed in the corners of the metall microhotplate (but not in contact with it). There are four external metal 2 connections.

b. Overglass openings centered on top of the metal2 pads.

The metal2 pads and overglass openings allow a substance (e.g., tin oxide and palladium) to be placed on top of the whole pixel. When heated, the resistance of the substance changes in the presence of certain gases. The metal2 acts as a van der Pauw sheet resistor so the resistance change can be measured. This application of the microhotplate is called a gas sensor. (NIST has a patent pending on this gas sensor design.)

\section{DESIGN IMPLEMENTATIONS AND RECOMMENDATIONS}

The design, submission, etching, and testing phases have been completed numerous times by micromachiners through MOSIS. The following implementations and recommendations are made based on experience gained from previous micromachine design submissions.

1. Include additional test structures in the designs intended for a post-processing EDP etch to help determine the completion of the etch step.

2. Include the design file layers in the open tile which have the effect of exposing the silicon 
surface to the ambient after the fabrication through MOSIS.

3. Include the design file layers in the pstop tile which have the effect of confining the post-processing etched region.

4. Adhere to the design rules given in this section for the open and pstop tiles for successful, reliable designs.

These four design implementations and recommendations are presented below in more detail.

\section{A. Structures to Include in the Design to Facilitate Etching}

Since most cavities have a designed feature suspended above them, the completion of the etching process is hard to observe with a microscope. Therefore, it is recommended that several open cavities be included in the design to mark the progress of the etch. Two recommended structures are:

1. A cavity without any suspended oxide. The design is simply a square of a digitized open tile the same size as the standard cavity size on the chip, say $80 \mu \mathrm{m} \times 80 \mu \mathrm{m}$, similar to the cell 'open-80x80' in the MEMS design library (see fig. 6).

2. A cavity with suspended oxide but no additional layers. The oxide is suspended like a trampoline (or whatever shape of suspended oxide is being used) without encompassing any polysilicon or metal. A trampoline-like suspended oxide requires that four trapezoidal open tiles closely surround a central undigitized area similar to the cell 'open-oxide-80x80' in the MEMS design library for an $80 \mu \mathrm{m} \times 80 \mu \mathrm{m}$ cavity (see fig. 7). During the EDP etch procedure, a microscope permits observation through this suspended oxide to determine whether the four open areas have merged and the underlying central column of silicon has collapsed. Viewing structure \#1 with a microscope helps adjust the focus for this structure to see if the cavity bottom has etched to a point for a digitized open square or to a line for a digitized, open rectangle.

It is recommended that structures be designed such that the sizes of the cavities for each micromachined chip are the same. However, if more than one cavity size is used, the etch time needs to permit the largest size cavity to be etched to completion. Negligible etching of the smaller cavities occurs once the bottom of the cavity has reached a point or line. Therefore, for chips with multiple-sized cavities, including the designs specified above for each size cavity is recommended.

\section{B. Design File Layers in the Open Tile}

When the open tile is digitized, there should be no other tiles (e.g., polysilicon or metal) digitized within this area. For double-metal processes, the digitized open tile consists of the design file layers active area, active contact, via, overglass opening, and an additional 'dummy' design file layer which does not appear on any masks but is called open as specified in the MOSIS SCMOS-MEM rules. [For triple-metal processes, the design layer via2 (metal3-to-metal2 via) is added.] The open layer is included to verify the proper layer stack, to avoid applying bonding pad checks, to stop any addition of layers (e.g., metal2 around the via), and to control any sizing that may need to be done at a later date. Table 1 gives the Caltech Intermediate Form (CIF) layer names and Calma numbers associated with the design file layers included in the open tile. Chip designs are submitted to MOSIS in a CIF or Calma GDS II Stream format. 
Table 1 - CIF Names and Calma Numbers Associated with the Design File Layers Included in the Open Tile

Design File Layer CIF Name Calma Number

\begin{tabular}{lll}
\hline & & \\
Active area & CAA & 43 \\
Active contact & CCA & 48 \\
Via & CVA & 50 \\
Overglass opening & COG & 52 \\
Open & COP & 23 \\
$*$ Via2 & CVS & 61 \\
\hline & \\
$*$ For triple-metal processes & \\
\hline
\end{tabular}

Therefore, with the design layers specified above defining the open area, the raw silicon substrate is exposed to the ambient (when the chips are received from MOSIS) to prepare for the post-processing etch. During the processing through MOSIS, however, polysilicon and metal cover the entire chip and are selectively removed with a subsequent etch defining their location. Due to the large vertical drop to the silicon substrate in the open areas, it may be difficult to completely remove all the polysilicon and metal at the edges of these areas. Hence, 'stringers' may be left behind around these edges. The deletion of the stringers is dependent upon the overetch of that layer for that particular processing run.

\section{Design File Layers in the Pstop Tile}

The digitized $p$ stop tile consists of the design file layers $p$-select, active area, and an additional 'dummy' design file layer which does not appear on any masks but is called pstop as specified in the MOSIS SCMOS-MEM rules. The $p$ stop layer has been added to control any sizing that may need to be done that is different from the $p$-select layer used in transistors. Also, if the $p$ stop layer is not included, it is not possible to distinguish the $p$ stop tile from the $p$-substrate diffusion tile in an $n$-well process since they are physically the same thing. Table 2 gives the CIF layer names and Calma numbers associated with the design file layers included in the pstop tile. 
Table 2 - CIF Names and Calma Numbers Associated with the Design File Layers Included in the Pstop Tile

\section{Design File Layer CIF Name Calma Number}

\begin{tabular}{lll} 
Active area & CAA & 43 \\
$P$-select & CSP & 44 \\
$P$ stop & CPS & 24 \\
\hline
\end{tabular}

The $p$ stop tile is not embedded in a well; it is intended to be used as an etch stop surrounding (but not encompassing) the outer edges of the resulting cavity. While the active area layer in the $p$ stop tile remains unsized and independent of feature size, the $p$-select layer is bloated 2 lambda unless otherwise determined from thermal cycling experiments. These experiments check for any mobile ion contamination to Metal-Oxide-Semiconductor Field-Effect Transistors (MOSFETs) at varying distances from an area exposed to the raw silicon surface as defined by the open tile. The contaminants can enter through the different layers of oxide at the open area edge, travel to a MOSFET gate, and affect the reliability of these MOSFETs. The design rules resulting from these experiments will be included in the MOSIS SCMOS-MEM rules.

\section{Design Rules for EDP Micromachining}

For most of the following design rules, the EDP etch time and temperature were $80 \mathrm{~min}$ at $92.0{ }^{\circ} \mathrm{C}$. Under these conditions an $80 \mu \mathrm{m} \times 80 \mu \mathrm{m}$ cavity was etched to completion and a $160 \mu \mathrm{m} \times 160 \mu \mathrm{m}$ cavity (having a trampoline-like suspended oxide) showed suspension. (A $180 \mu \mathrm{m} \times 180 \mu \mathrm{m}$ cavity with a trampoline-like suspended oxide has not achieved suspension. There is still a remaining central column of silicon requiring a longer etch time for its removal.)

The 80 -min etch time of the $80 \mu \mathrm{m} \times 80 \mu \mathrm{m}$ cavity and the $54.74^{\circ}$ crystallographic angle of the cavity surfaces with respect to the horizontal lead to a vertical etch rate of $0.7 \mu \mathrm{m} / \mathrm{min}$.

i. Design Rules for the Open Tile

1. No other layers should exist within the digitized open tile.

2. The minimum open width is $5 \mu \mathrm{m}$.

3. For distinct cavities, the minimum open-to-open spacing is $8 \mu \mathrm{m}$. This rule assumes a maximum $200-\mu \mathrm{m}$ digitized open edge. For larger cavities, $8 \mu \mathrm{m}$ may not be enough spacing.

4. For the same resulting cavity, the minimum open-to-open spacing is $0 \mu \mathrm{m}$.

5. The minimum spacing between the open layer and poly1, poly 2 , metal1, metal2, and metal 3 is $5 \mu \mathrm{m}$.

6. The minimum spacing between the open layer and a reliable MOSFET is to be determined with thermal cycling experiments to check for mobile ion contamination. 
7. The five design layers (comprising the open tile) are active area, active contact, via, overglass opening, and open which have coincident edges (there are six layers when via2 is included for triple-metal processes). The thermal cycling experiments mentioned above could also indicate a need for a reasonable stepping down of the oxides to the substrate for improved reliability of neighboring MOSFETs.

\section{ii. Design Rules for the $P$ stop Tile}

1. The minimum width of the $p$ stop tile (consisting of the design file layers active area, $p$-select, and $p$ stop) is $5 \mu \mathrm{m}$ which is independent of feature size. The $p$-select layer is currently being bloated an additional 2 lambda. (This 2-lambda bloat may be changed depending upon the results of the thermal cycling experiments.)

2. The minimum spacing between the pstop and open tiles is $0 \mu \mathrm{m}$. In fact, it is intended to have the $p$ stop tile butt up against the open tile. This implies that, post-CIF, the bloated CSP layer from the pstop tile overlaps the open tile by 2 lambda, which is acceptable. This 2-lambda bloat is contingent upon the results of the thermal cycling experiments.

3. The minimum spacing between the $p$ stop tile and any outside circuitry is the same spacing as $p$-substrate diffusion in an $n$-well process to that circuitry unless the thermal cycling experiments prove otherwise.

4. It is a good (but not a mandatory) practice to avoid placing any other tiles on top of the $p$ stop tile to minimize possible transistor action. However, for the safety of normal CMOS operation, the pstop tile should be biased to ground (or the lowest potential on the chip) to avoid any $p n$-junction conduction.

\section{THE ETCHANT}

When the chips are received from MOSIS, a post-processing anisotropic etch is performed to realize the suspended structures. The etchant used, ethylenediamine-pyrocatechol water (EDP), was chosen because both $\mathrm{SiO}_{2}$ and $\mathrm{Al}$ can be used as masking materials. For an 80-min etch time, the etchant does not attack the surface of CMOS chips covered by $\mathrm{SiO}_{2}$ for passivation or the exposed aluminum bond pads. Therefore, the only areas exposed to the etchant are the open areas defined by the open tiles in the CAD layout. These factors give rise to a maskless etch procedure for realizing the suspended structures in standard CMOS processes.

In the case of a square or rectangular opening in the $\mathrm{SiO}_{2}$ that is aligned to the crystallographic axes, the opening exposes the Si surface initially. After some intermediate time in the anisotropic etch, a flat-bottomed cavity is formed. The side walls of the cavity are bounded by the $\{111\}$ planes which form a $54.74^{\circ}$ angle with respect to the silicon surface plane. The material being etched is primarily at the bottom of the cavity. After some final time, the four walls intersect at a point or the cavity bottom becomes a line and the etching basically halts.

The etch rate varies with the direction in the silicon crystal lattice, hence the term anisotropic etch. Of primary importance is the fact that the etch rate is significantly slower in the $\langle 111\rangle$ direction as compared to the $\langle 100\rangle$ direction. The approximate ratio for the etchant used in this work for these two directions is $1: 35$. Therefore, the $\{111\}$ planes can virtually be used as etch stops. There is some undercutting of the $\mathrm{Si}-\mathrm{SiO}_{2}$ surface because the etch rate is not completely negligible in the $\langle 111\rangle$ direction. This 
undercutting can be minimized by incorporating a $p^{+}$boron implant at the perimeter of the open area. This is the pstop design tile described in Sections II and IV.

To reduce the health risks associated with mixing these chemical substances, NIST obtains the EDP premixed from outside sources.

Individuals interested in replicating the NIST/MOSIS method of micromachining are referred to Section XI.

\section{ETCH TIME AND TEMPERATURE}

The etch time depends upon the 'freshness' of the etchant as well as the size of the desired cavity. For $80 \mu \mathrm{m} \times 80 \mu \mathrm{m}$ etched cavities, etch times of 60 to $80 \mathrm{~min}$ at $92.0^{\circ} \mathrm{C}$ are recommended. These times assume 'fresh' EDP etchant (i.e., etchant that has not been used before). Used etchant is more brownish in color indicating the presence of oxygen. The etch rate for 'already used' etchant is a lot faster, requiring 45 to $60 \mathrm{~min}$ to completely etch an $80 \mu \mathrm{m} \times 80 \mu \mathrm{m}$ cavity. Logically, larger cavities require a longer etch time, and higher temperatures require shorter etch times. The etch process is monitored by viewing the chips periodically under a microscope to see if the cavities are completely etched. When this occurs, the bottom of the cavity is a point when the inverted pyramidal base is a square and is a line when the base of the inverted pyramidal-shaped trench is a rectangle.

\section{THE HAZARDS AND PRECAUTIONS ASSOCIATED WITH THE EDP ETCHANT}

The user is reminded to read the Material Safety Data Sheets (MSDSs) supplied by Occupational Health Services, Inc. (OHS, Inc.) for the substances ethylenediamine, catechol, and pyrazine (which comprise the EDP used in this work) before beginning to work with this etchant. These MSDSs include the following information:

1. Chemical products and company identification

2. Composition/information on ingredients

3. Hazards identification

4. First aid measures

5. Fire fighting measures

6. Accidental release measures

7. Handling and storage

8. Exposure controls/personal protection

9. Physical and chemical properties

10. Stability and reactivity

11. Toxicology information

12. Ecological information

13. Disposal information

14. Transportation information

15. Regulatory information

16. Other

Ethylenediamine-pyrocatechol water is a harmful chemical, and the above information should be well understood and followed. These MSDSs will accompany the MEMS chips from MOSIS. It is NOT recommended for students to work with this chemical etchant. 
A semiconductor processing facility may decide not to allow EDP in the facility because of the possibility of contaminating other processes within the facility.

\section{EQUIPMENT NEEDED FOR THE EDP ETCH (in the order in which it is used)}

1. Gloves, goggles, and body suit to avoid contact with the EDP solution.

2. Respirator, if needed (consult Section 8 of the MSDSs in the Appendices), to avoid inhalation of the EDP vapors.

3. Exhaust hood under which to perform the etch with a nearby sink under the hood.

4. Hot plate with magnetic stirring capabilities. The stirrer is typically pellet-shaped.

5. A thermocouple to sense the temperature of the EDP etchant.

6. Nitrogen gas to purge the reflux container (described in \#8) since air introduces oxygen into the etchant, changing the etch rate.

7. Cold tap water to circulate through the lid of the reflux container.

8. A 12.7-cm (5-in.) -diameter reflux container (see fig. 14). This looks like a 12.7-cm (5-in.) -diameter beaker with a lid through which cold water circulates. Out the botton of the lid protrudes the housing for a thermocouple. The nitrogen gas enters through the top along with the thermocouple and comes out a hole approximately halfway down the rod extending down from the lid which houses the thermocouple. Etchant vapor condensation keeps the etchant at approximately the same concentration. This process is call refluxing.

9. Temperature display which digitally displays the temperature sensed by the thermocouple in degrees Celsius. This is connected to the thermocouple which is inserted into the protruding part of the lid of the reflux container from the top of the lid.

10. A $12.7-\mathrm{cm}(5-\mathrm{in}$.) -diameter beaker to temporarily place the reflux container lid on periodically throughout the etching procedure.

11. Approximately $1 \mathrm{~L}$ of EDP etchant.

12. A non-copper funnel for pouring the etchant.

13. Custom-made teflon carrier designed for etching chips or packages and meeting these criteria:

a. The carrier fits into the reflux container without being in the way of the housing for the thermocouple.

b. The magnetic stirrer does not harm the chips or packages to be etched.

c. The chips or packages do not touch one another throughout the etching. Chips may require individual compartments, but the compartments need to be exposed to the etchant. Packages etch well when inserted back-to-back into 'slots.'

d. A handle with which to retrieve the carrier.

14. Chips or packages to be etched.

15. Custom-made teflon carrier retriever (basically a long-handled rod with a hook on the end to lift out the chip or package carrier).

16. Timer for measuring etch times up to $2 \mathrm{~h} \pm 1 \mathrm{~min}$.

17. Deionized (DI) water.

18. Petri dish (or deeper container).

19. Tweezers.

20. A $100 \mathrm{X}$ microscope to check the progress of the etchant by observing the test structures in Section IV.A. 


\section{AN EDP ETCHING PROCEDURE}

1. The user is reminded to read all directions before beginning, including the MSDSs supplied by OHS, Inc. in Appendices A through $\mathrm{C}$.

2. Given the size of the cavity(ies) to be etched, estimate an etch time. (Refer to Section VI entitled 'Etch Time and Temperature.')

3. Put on the goggles, gloves, and appropriate safety garments and gear as deduced from the instructions in Section 8 of the MSDSs.

4. The following steps are done under an exhaust hood with at least one other responsible person present. [After use, the apparatus is rinsed with DI water.]

5. Place the bottom of the reflux container on top of the magnetic hot plate (not yet turned on) and put the magnetic stirrer in the bottom of this container. Put on the lid of the reflux container with the thermocouple inserted into the protruding bottom portion of the lid. Turn on the temperature display.

6. Connect the nitrogen gas to the reflux container and start the flow of nitrogen gas into the container.

7. Begin slowly circulating the cold water into the lid of the reflux container, draining it into the sink.

8. Carefully remove the lid of the reflux container (with the water still circulating) and temporarily place it in a neighboring $12.7-\mathrm{cm}$ (5-in.) -diameter beaker. With the funnel, pour approximately $1 \mathrm{~L}$ of the EDP etchant into the bottom of the reflux container while avoiding the hazardous vapors and avoiding skin contact with the etchant. Put the lid of the reflux container promptly on top of the container to avoid the escape of additional fumes. Re-cap the empty bottle of etchant which will be used later.

At this point the EDP etchant should be in the bottom of the reflux container with the magnetic stirrer. Nitrogen gas is circulating above it, and in the lid of the reflux container, cold water is circulating and draining into the sink. The temperature of the liquid is readable on the temperature display.

9. Turn on the magnetic stirrer for a gently moving stir.

10. Turn on the hot plate and allow the temperature of the EDP etchant to rise to $92.0^{\circ} \mathrm{C}$ without overshooting. It may take 15 to $30 \mathrm{~min}$ to achieve this constant temperature. Reduce the power to the hotplate when the temperature reaches about $88.0^{\circ} \mathrm{C}$ to reduce the likelihood of temperature overshoot.

While waiting for a constant $92.0^{\circ} \mathrm{C}$ temperature of the EDP solution, place the chips (or packages with lids removed) into the custom-made teflon carrier, and practice lifting the carrier with the teflon carrier retriever.

11. When a $92.0^{\circ} \mathrm{C}$ temperature is maintained, temporarily turn off the magnetic stirrer. Place the lid of the reflux container in the neighboring $12.7-\mathrm{cm}$ (5-in.) -diameter beaker (if the temperature goes down, it will recover when the lid is replaced). 
12. With the teflon carrier retriever, carefully insert the teflon carrier (with chips or packages) to the bottom of the reflux container.

13. As soon as possible, put the lid of the reflux container back on. This prevents a significant change in the concentration of the EDP etchant which could change the heat required to get the EDP etchant to $92.0^{\circ} \mathrm{C}$.

14. Turn on the magnetic stirrer.

15. When bubbles start coming off the chips, start the timer. Bubbles should appear within 3 min after the chips are placed in the etchant. The bubbles indicate the etchant is etching; they are more noticeable on chips whose underside is being etched at the same time. It can be hard to see bubbles when etching packaged parts, so activate the timer approximately $1 \mathrm{~min}$ after they are immersed.

16. Recall the etch time estimated for this procedure in Step \#2.

17. The etch can be interrupted periodically to monitor its progress by observing the etched cavities on the chips or packages with a microscope after they have been dipped in DI water. The first

observation can be made about 15 min before the estimated etch time is complete, and after that, it is up to the researcher.

To observe, remove the reflux container lid, extract the teflon carrier with the retriever, replace the lid, stop the timer, and place the chips or packages in a petri dish (or deeper container) full of DI water with a pair of tweezers. A drop of DI water left on the chip can help with this microscopic visual determination; however, it is not necessary. If the structures shown in figures 6 and 7 and mentioned in Section IV.A, 'Structures to Include in the Design to Facilitate Etching,' were included in the chip design, examine these structures in the manner specified in that section. When the cavity bottoms have been etched to a point or a line, the etching is complete. If these test structures do not exist on the chip, make a best determination from existing structures.

18. Return the chips or packages to the reflux container and reactivate the timer to continue etching if needed. Repeat the previous step, examining the chips or packages at intervals of time until etching is complete.

19. Turn off the magnetic stirrer, hotplate, and nitrogen gas.

20. At the completion of visual inspection, the petri dish (or deeper container) with the chips or packages is full of DI water. Place this dish in the sink and let DI water trickle into it to get rid of any gray residue. The water flow should be set such that there is no chip or package movement in the petri dish (or deeper container) but such that the DI water will not turn gray when the parts are retrieved (this takes practice). The parts should be retrieved several hours later (or the next day) at which time the water should be turned off. Meanwhile, proceed to steps 21 and 22 .

21. Soak the teflon carrier in DI water several times to remove the gray etching residue.

22. When the EDP etchant has cooled to near room temperature, return the EDP to the bottle it came in with a funnel. Clean the apparatus that has been in contact with the etchant with DI water. Store the EDP in a cool place away from acids. Consult the MSDSs in the Appendices for more complete storing information (Sec. 7) and for information regarding the proper disposal procedures (Sec. 13). 
23. After the chips or packages have remained in DI water for several hours or overnight, remove the chips or packages from the DI water and dry them with a nitrogen jet.

\section{NOTE ON ETCHING PACKAGED PARTS}

To date, chips from MOSIS have been successfully etched and tested. For packaged parts from MOSIS, it has been demonstrated that the wire bonds and epoxy used to secure the chips to the package can withstand an EDP etch intended to etch $80 \mu \mathrm{m} \times 80 \mu \mathrm{m}$ cavities. The packaged parts are electrically reliable after the EDP etch; however, bonding reliability issues need to be addressed with bond-wire pull tests.

\section{FOR FURTHER INFORMATION}

A. Health and Safety Information

Any questions related to the MSDSs should be directed to:

Occupational Health Services, Inc.

11 West 42nd Street, 12th floor

New York, NY 10036

1-800-445-MSDS (1-800-445-6737) or

$1-212-789-3535$

For emergency source information, call:

$1-615-266-2000$

B. General Information, Technology Files, and the MEMS Library

Please initially direct any questions to MOSIS, by sending an attention message to 'mosis@mosis.edu.'

\section{REQUEST: ATTENTION}

MOSIS has released a revised 'scmos' Magic technology file to support the open and pstop tiles. This technology file along with the MEMS library is obtainable through MOSIS using the information request method below:

\section{REQUEST: INFORMATION}

TOPIC: scmos_tech.uu

REQUEST: LIBRARY

LIBRARY: NIST-MEMS-1

FILES: open-80x80.cif, open-oxide-80x80.cif

FILES: thermal-converter.cif, thermal-actuator.cif

FILES: pixel-80x80.cif, pixel-160x160.cif

FILES: micro-hot-plate.cif, gas-sensor.cif

FILES: memslib.cif

REQUEST: END 


\section{CAD MEMS Support}

Tanner Research will also release support for MEMS designs with the CAD tool L-Edit. The designer may contact:

Tanner Research, Inc.

180 North Vinedo Avenue

Pasadena, CA 91107

1-818-792-3000 FAX 1-818-792-0300

D. Micromachining Information

Researchers who wish to consult with NIST may contact:

Michael Gaitan

NIST

Technology Bldg, Rm B-360

Gaithersburg, MD 20899

1-301-975-2070 FAX 1-301-948-4081

gaitan@sed.eeel.nist.gov

E. Additional Information

Further background information is available in the references.

\section{ACKNOWLEDGMENTS}

The outstanding contributions of R. L. Mattis and C. E. Schuster from NIST are gratefully acknowledged, along with the editorial assistance of J. M. Rohrbaugh. Acknowledgments are also given to the following people at NIST: M. R. Rubin, M. D. Edelstein, C. A. Zincke, H. A. Schaff, L. W. Linholm, R. J. Mele, E. J. Walters, F. F. Oettinger, J. F. Mayo-Wells, and J. C. French.

K. S. J. Pister from UCLA is also acknowledged.

\section{REFERENCES}

A. Some Background Articles:

[1] J. C. Marshall, M. Parameswaran, M. E. Zaghloul, and M. Gaitan, High-Level CAD Melds Micromachined Devices with Foundries, IEEE Circuits and Devices, vol. 8, no. 6, pp. 10-17, November 1992.

[2] K. D. Wise and N. Najafi, The Coming Opportunities in Microsensor Systems, Proceedings of Transducers '91, pp. 2-7, June 1991.

[3] M. Parameswaran, H. P. Baltes, Lj. Ristic, A. C. Dhaded, and A. M. Robinson, A New Approach for the Fabrication of Micromachined Structures, Sensors and Actuators, vol. 19, pp. 289-307, 1989. 
[4] K. E. Petersen, Silicon as a Mechanical Material, Proceedings of the IEEE, vol. 70, no. 5, pp. 420-457, 1982.

B. Some CAD-Related Articles:

[5] C. A. Zincke, M. Gaitan, M. E. Zaghloul, and L. W. Linholm, Test Structures for Determining Design Rules for Microelectromechanical-Based Sensors and Actuators, 1994 IEEE International Conference on Microelectronic Test Structures, pp. 44-50, 1994.

[6] C. Tomovich, ed., MOSIS User Manual, University of Southern California, 1988.

[7] W. S. Scott, R. N. Mayo, G. Hamachi, and J. K. Ousterhout, 1986 VLSI Tools: Still More Works by the Original Artists, Report \# UCB/CSD 86/272, Computer Science Division (EECS), University of California, Berkeley, California, December 1985.

[8] J. K. Ousterhout, The User Interface and Implementation of an IC Layout Editor, IEEE Trans. on Computer-Aided Design, vol. CAD-3, no. 3, pp. 242-249, July 1984.

C. Some Micromachining Applications:

[9] D. Moser, O. Brand, and H. Baltes, A CMOS Compatible Thermally Excited Silicon Oxide Beam Resonator with Aluminum Mirror, Proceedings of Transducers '91, pp. 547-550, June 1991.

[10] M. Parameswaran, A. M. Robinson, D. L. Blackburn, M. Gaitan, and J. Geist, Micromachined Thermal Radiation Emitter from a Commercial CMOS Process, IEEE Electron Device Letters, vol. 12, no. 2, pp. 57-59, February 1991.

[11] M. Parameswaran, A. M. Robinson, Lj. Ristic, K. Chau, and W. Allegretto, A CMOS Thermally Isolated Gas Flow Sensor, Sensors and Materials, vol. 2, pp. 17-26, 1990.

[12] A. P. Pritchard, Dynamic IR Scene Generation: Basic Requirements and Comparative Display Design, Proc. SPIE, vol. 940, pp. 144-149, 1988.

[13] R. T. Howe and R. S. Muller, Polycrystalline Silicon Micromechanical Beams, J. Electrochem. Soc., pp. 1420-1423, June 1983.

D. Some Etch-Related Articles:

[14] C. H. Sequin, Computer Simulation of Anisotropic Crystal Etching, Proceedings of Transducers '91, pp. 801-806, June 1991.

[15] H. Seidel, L. Csepregi, A. Heuberger, and H. Baumgartel, Anisotropic Etching of Crystalline Silicon in Alkaline Solutions, I. Orientation Dependence and Behavior of Passivation Layers, J. Electrochem. Soc., vol. 137, no. 11, pp. 3612-3626, November 1990.

[16] H. Seidel, L. Csepregi, A. Heuberger, and H. Baumgartel, Anisotropic Etching of Crystalline Silicon in Alkaline Solutions, II. Influence of Dopants, J. Electrochem. Soc., vol. 137, no. 11, pp. 3626-3632, November 1990. 
[17] A. Reisman, M. Berkenblit, S. A. Chan, F. B. Kaufman, and D. C. Green, The Controlled Etching of Silicon in Catalyzed Ethylenediamine-Pyrocatechol-Water Solutions, Solid-State Science and Technology, vol. 126, no. 8, pp. 1406-1415, August 1979.

[18] E. Bassous, Fabrication of Novel Three-Dimensional Microstructures by the Anisotropic Etching of (100) and (110) Silicon, IEEE Trans. Electron Devices, vol. ED-25, no. 10, pp. 1178-1185, 1978.

[19] K. E. Bean, Anisotropic Etching of Silicon, IEEE Trans. Electron Devices, vol. ED-25, no. 10, pp. 1185-1192, 1978.

[20] A. Bohg, Ethylene Diamine-Pyrocatechol-Water Mixture Shows Etching Anomaly in Boron Doped Silicon, J. Electrochem. Soc., vol. 118, p. 401, 1971. 


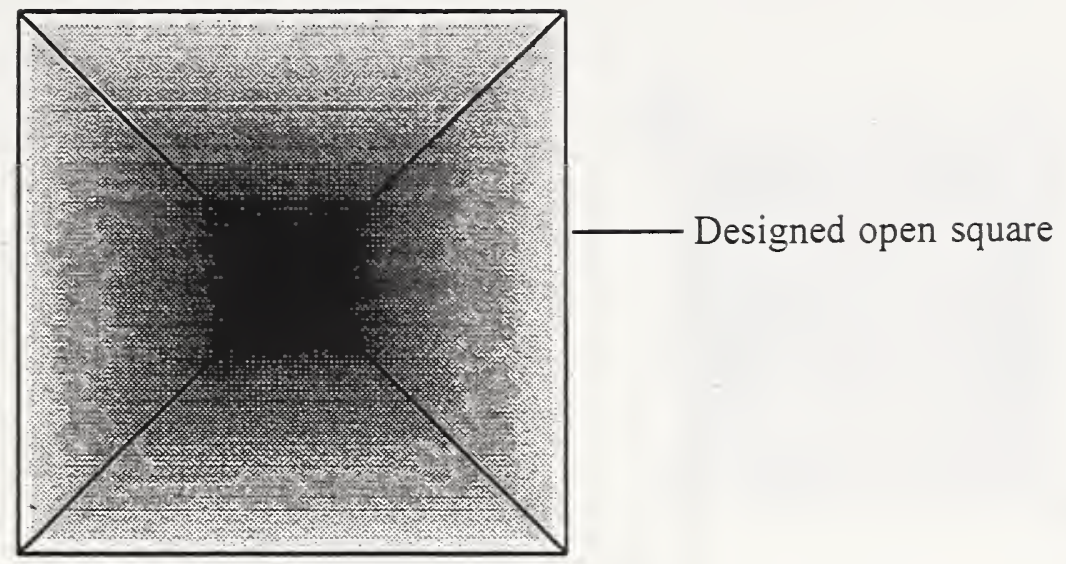

Figure 1. Top view of an inverted pyramid. The bottom of this cavity is a point.

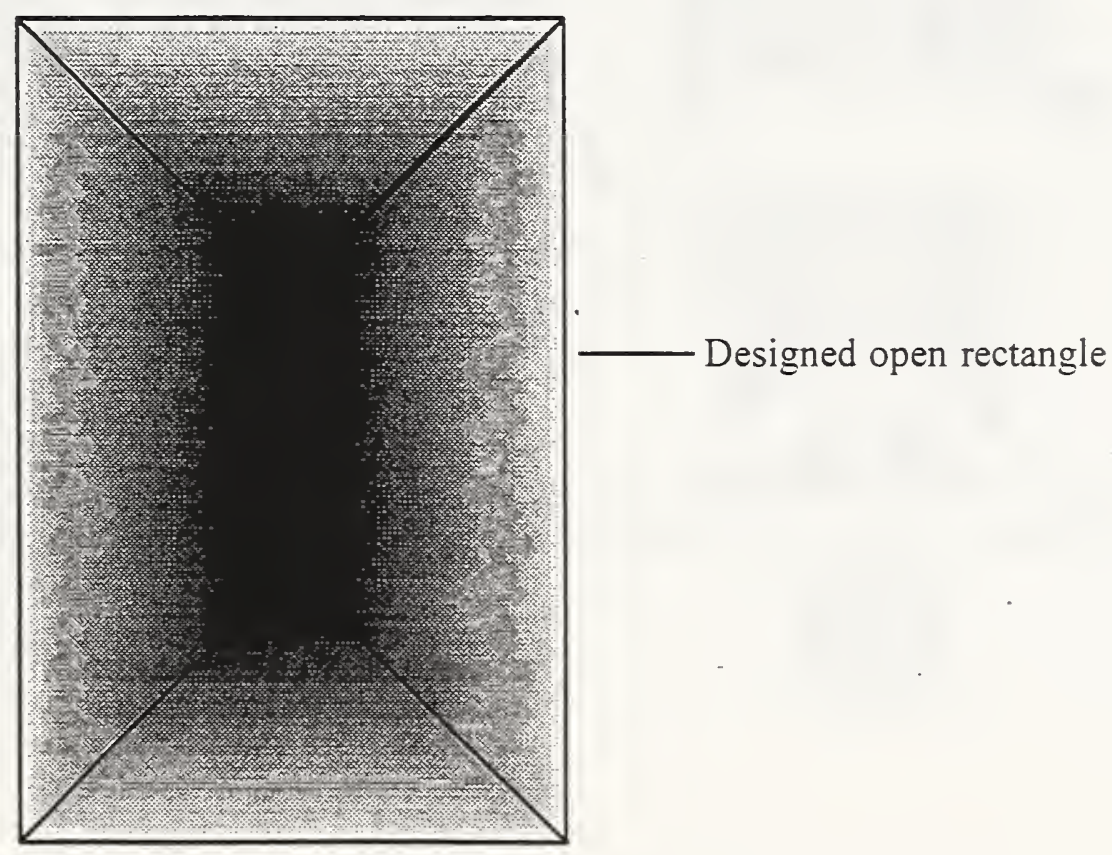

Figure 2. Top view of an inverted pyramidal-shaped trench. The bottom of this cavity is a line. 


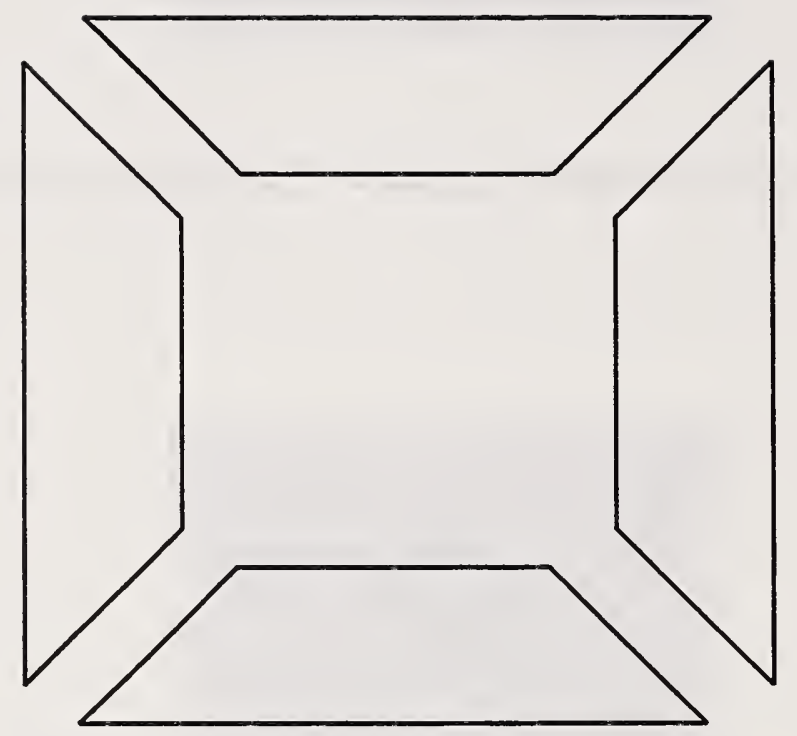

Figure 3. Four trapezoidal open tiles used to design a pixel with a trampoline-like suspended oxide in the center held up by four support beams which are also suspended. 


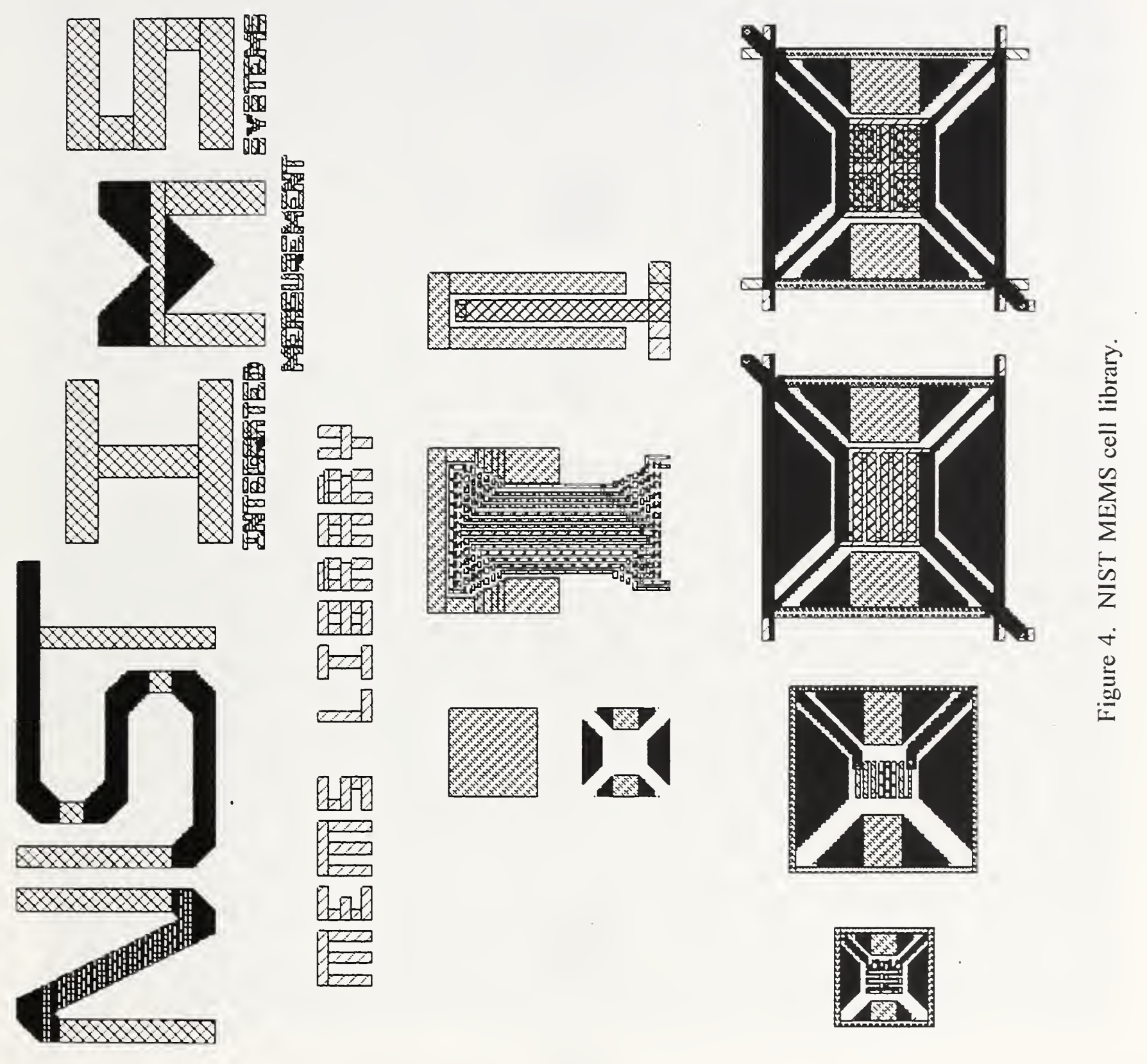


Open

Pstop

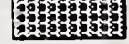

Polysilicon

Polycontact

Metal 1

Metal2

18 Metal2contact

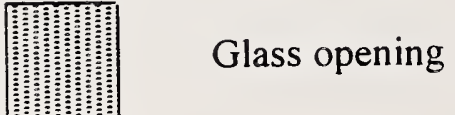

Figure 5. Key to the shading in the figures. 


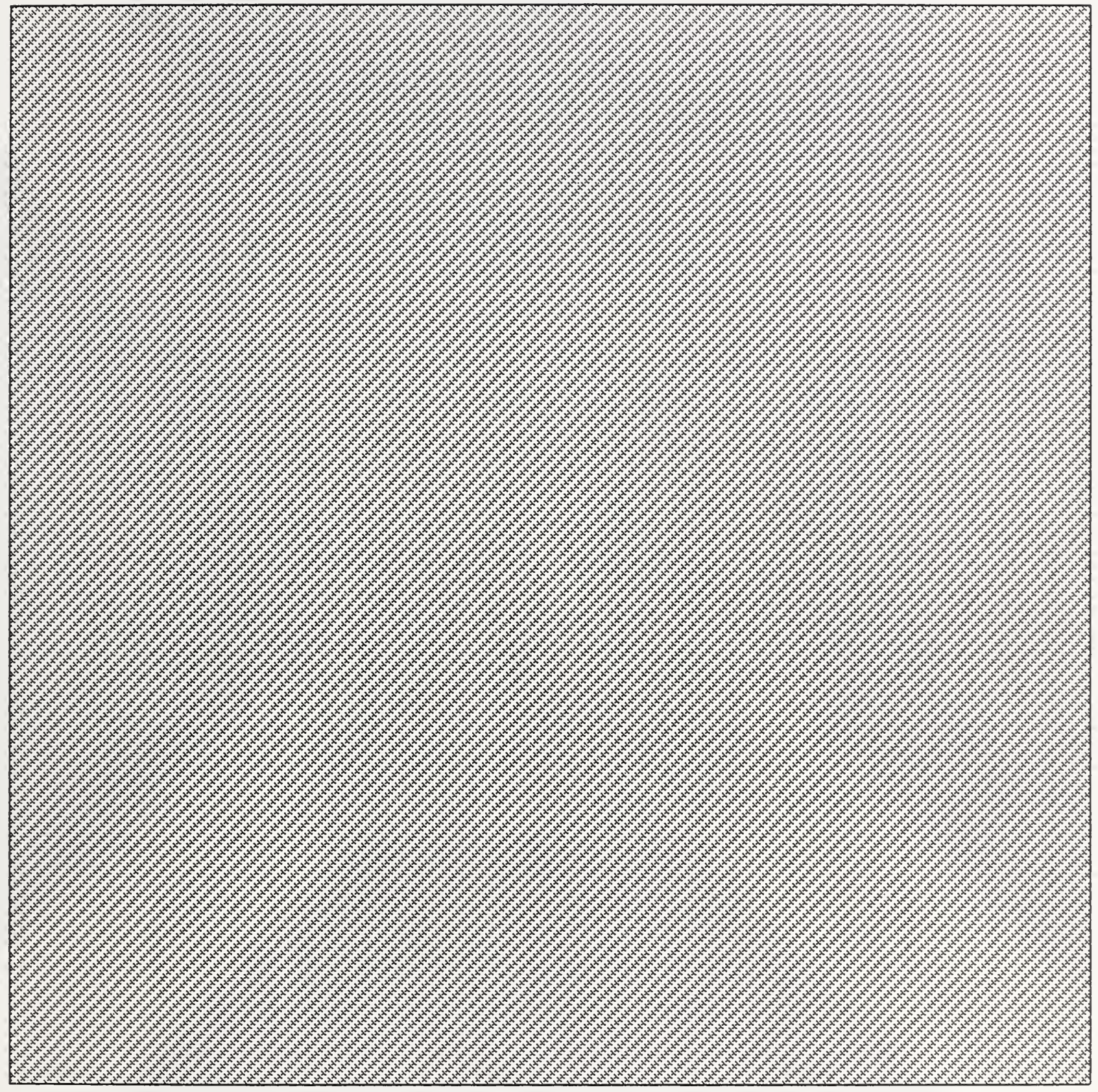

Figure 6. MEMS test structure with cell name 'open- $80 \times 80$ ' used to check the progress of the EDP etchant on an intended $80 \mu \mathrm{m} \times 80 \mu \mathrm{m}$ cavity. 


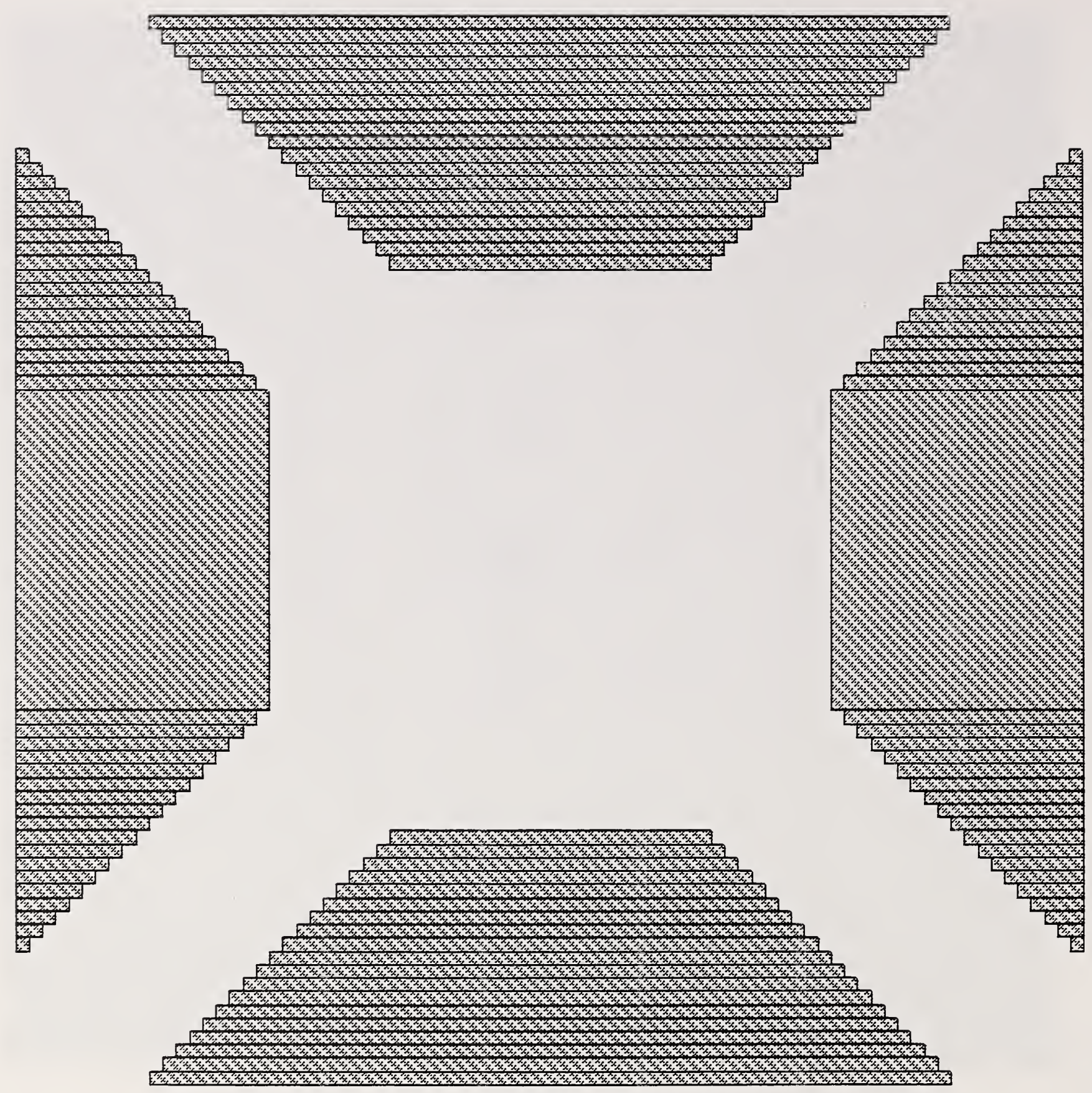

Figure 7. MEMS test structure with cell name 'open-oxide- $80 \times 80$ ' used to check the progress of the EDP etchant on an intended $80 \mu \mathrm{m} \times 80 \mu \mathrm{m}$ cavity with a trampoline-like suspended oxide. 


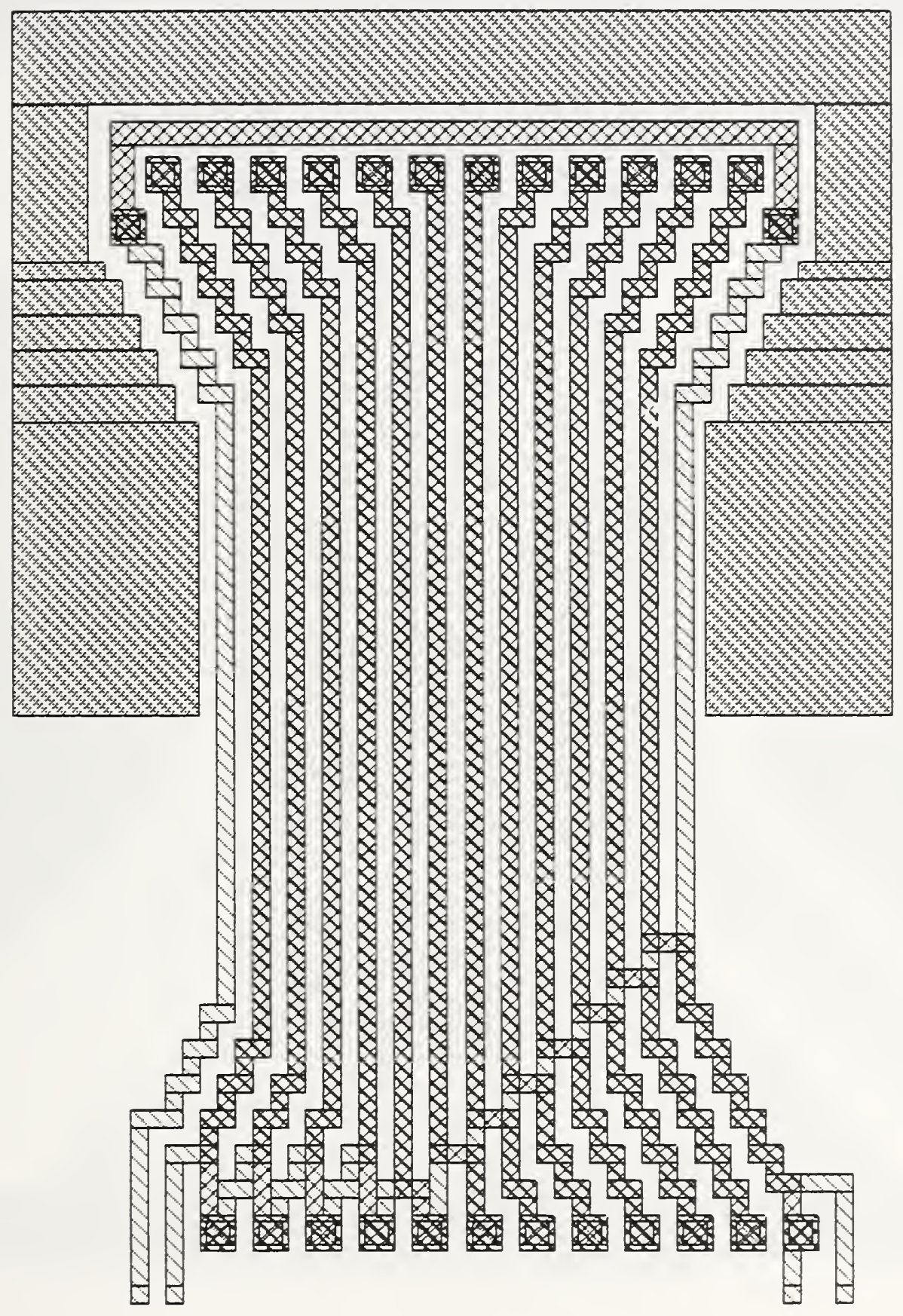

Figure 8. MEMS test structure with cell name 'thermal-converter' used as an ac power sensor. 


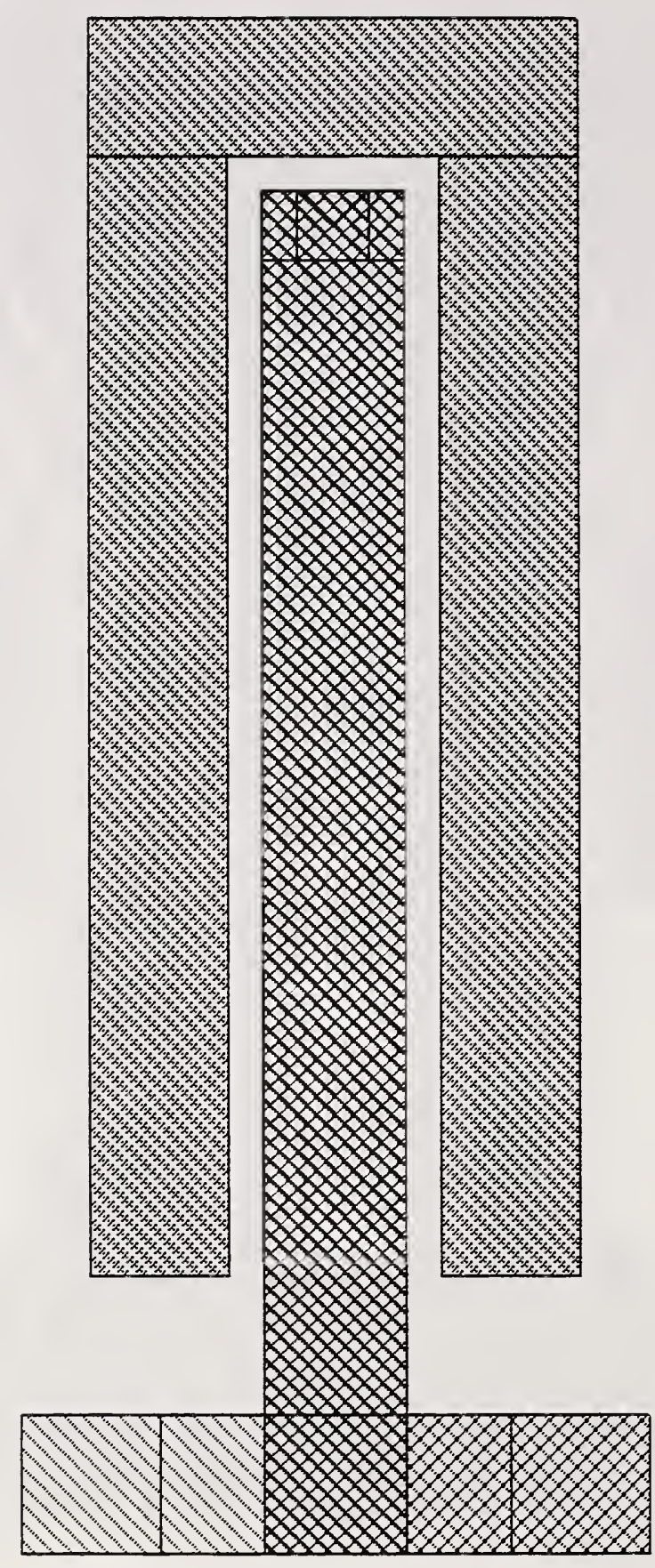

Figure 9. MEMS test structure with cell name 'thermal-actuator' used to exhibit thermal responses of a cantilever structure. 


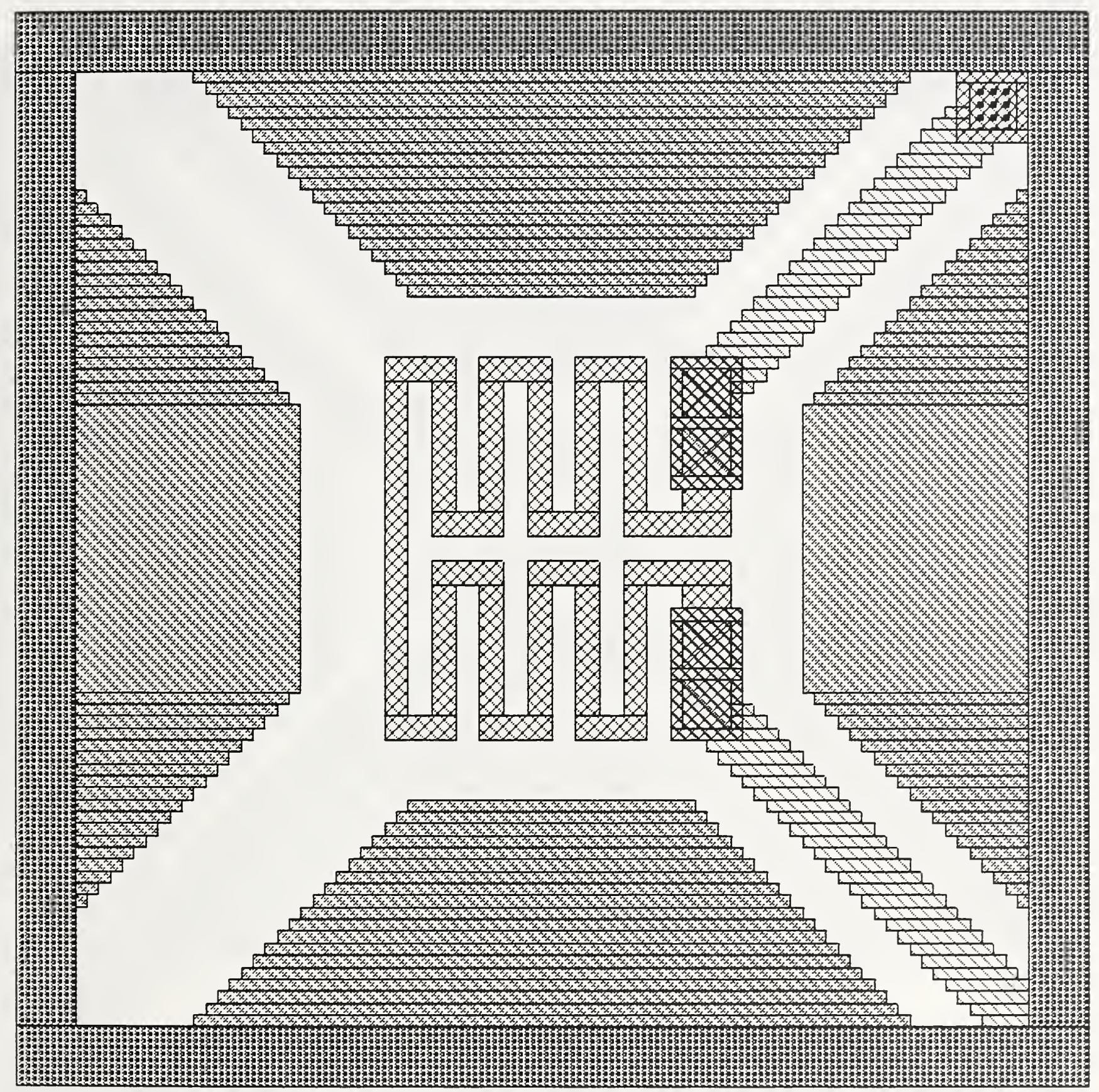

Figure 10. MEMS test structure with cell 'name 'pixel-80x80' used as a heating element with an $80 \mu \mathrm{m} \times 80 \mu \mathrm{m}$ cavity. 


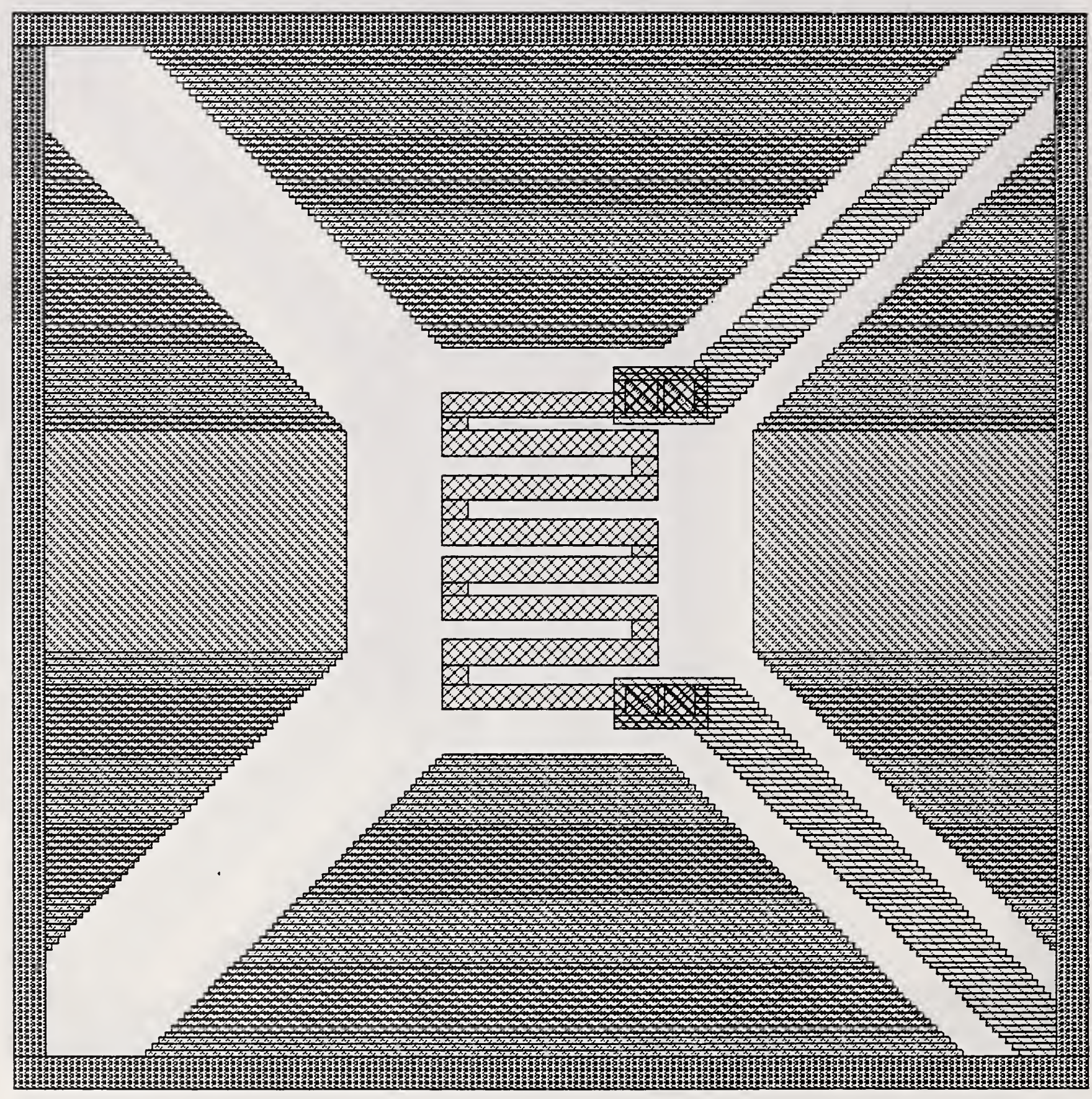

Figure 11. MEMS test structure with cell name 'pixel-160x160' used as a heating element with a $160 \mu \mathrm{m} \times 160 \mu \mathrm{m}$ cavity. 


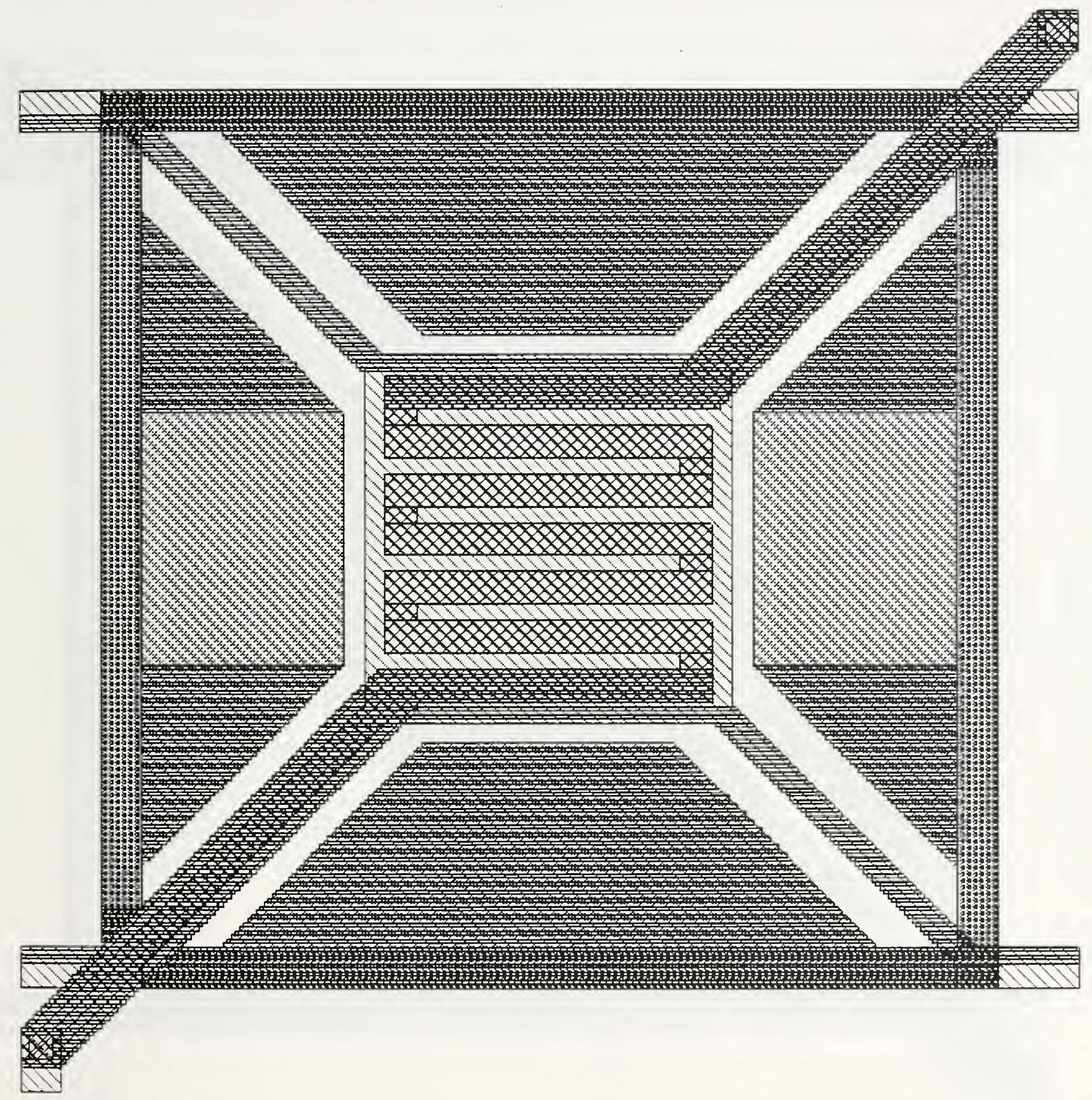

Figure 12. MEMS test structure with cell name 'micro-hot-plate' used as a microhotplate. 


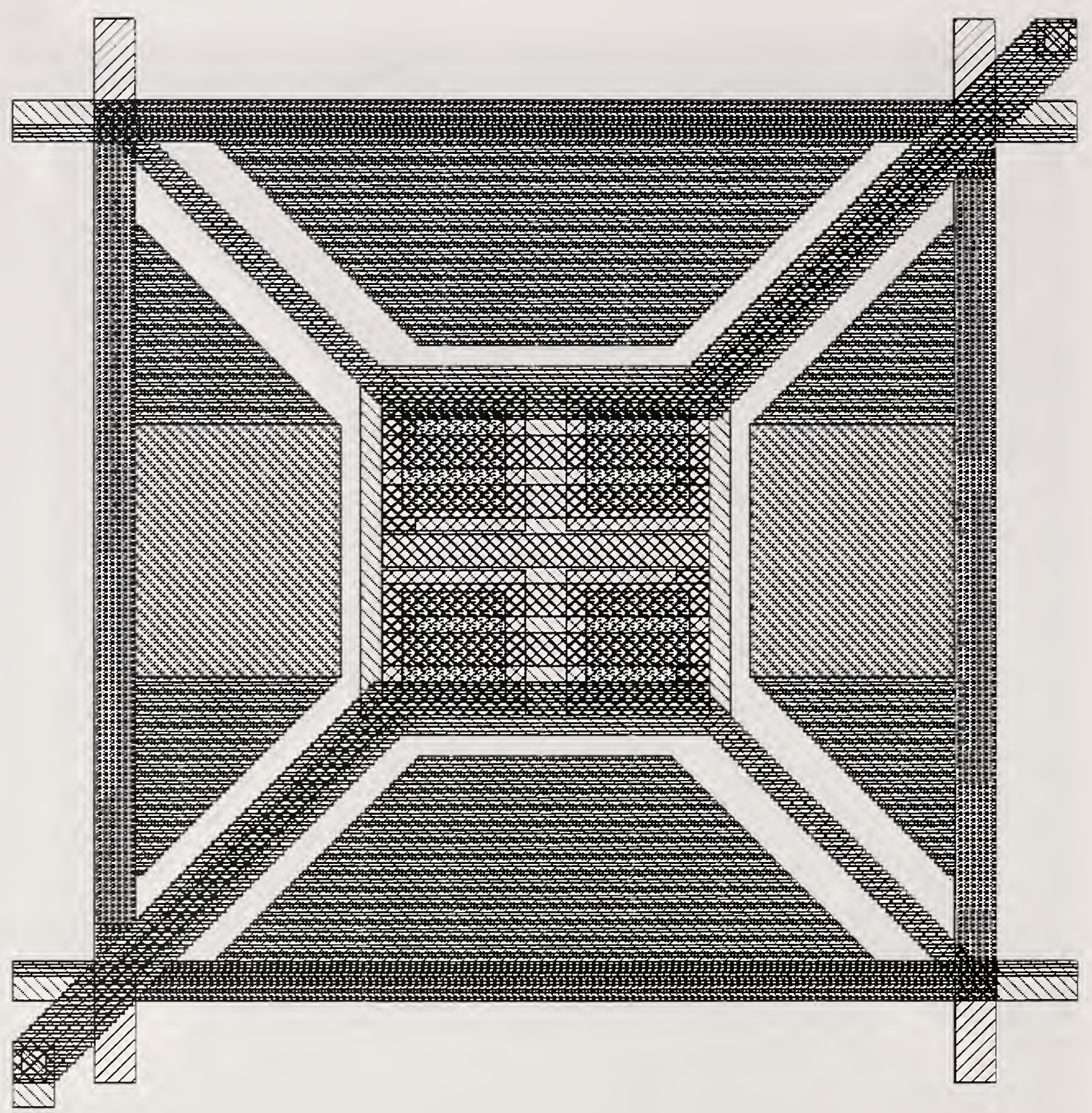

Figure 13. MEMS test structure with cell name 'gas-sensor' used as a gas sensor. 


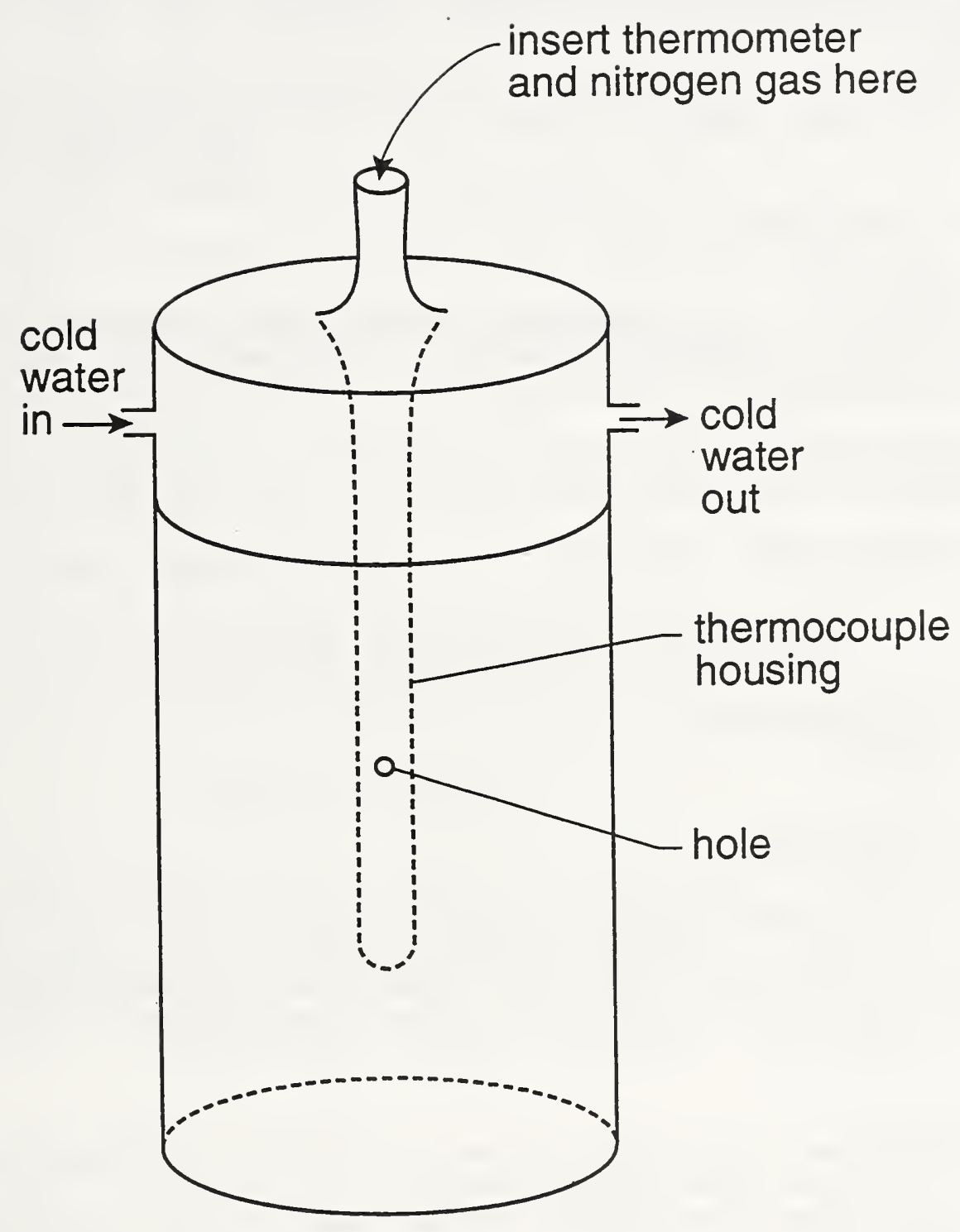

Figure 14. Diagram of the reflux container. 
APPENDIX A. THE MSDS FOR THE SUBSTANCE ETHYLENEDIAMINE

OHSO9560

SECTION 1

CHEMICAL PRODUCTS \& COMPANY IDENTIFICATION

OCCUPATIONAL HEALTH SERVICES, INC.

FOR EMERGENCY SOURCE INFORMATION

11 WEST 42ND STREET, 12TH FLOOR

CONTACT: $1-615-366-2000$

NEW YORK, NEW YORK 10036

1-800-445-MSDS (1-800-445-6737) OR

$1-212-789-3535$

CAS NUMBER: 107-15-3

RTECS NUMBER: KH 8575000

SUBSTANCE : ETHYLENEDIAMINE

TRADE NAMES/SYNONYMS:

1,2-DIAMINOETHANE; 1,2-ETHYLENEDIAMINE; DIAMINOETHANE; ETHYLENDIAMINE; BETA-AMINOETHYLAMINE; DIMETHYLENEDIAMINE; 1,2-ETHANEDIAMINE; STCC 4935628; UN 1604; C2H8N2; OHS09560

CHEMICAL FAMILY:

AMINE, ALIPHATIC

CREATION DATE: $12 / 10 / 84$

REVISION DATE: 03/24/93

SECTION 2

COMPOSITION/INEORMATION ON INGREDIENTS

COMPONENT : ETHYLENEDIAMINE

CAS NUMBER: 107-15-3

PERCENTAGE: 100.0

OTHER CONTAMINANTS: NONE.

SECTION 3

HAZARDS IDENTIFICATION

CERCLA RATINGS (SCALE 0-3): HEALTH=2 FIRE=3 REACTIVITY=0 PERSISTENCE $=0$ NFPA RATINGS (SCALE 0-4): HEALTH=3 FIRE=2 REACTIVITY=0

EMERGENCY OVERVIEW:

ETHYLENEDIAMINE IS A COLORLESS TO YELLOW LIQUID WITH AN AMMONIA-LIKE ODOR. YOU CAN SMELI IT AT 10 PARTS PER MILIION.

MAY BE FATAL IF INHALED. HARMFUL IF ABSORBED THROUGH SKIN. HARMFUL IF

SWALLOWED. CAUSES RESPIRATORY TRACT, SKIN AND EYE BURNS. CAUSES SEVERE BURNS

TO MUCOUS MEMBRANES. MAY CAUSE (SEVERE) ALLERGIC RESPIRATORY REACTION. MAY CAUSE ALIERGIC SKIN REACTION. FLAMMABLE LIQUID AND VAPOR. MAY CAUSE FLASH FIRE.

POISON. DO NOT BREATHE VAPOR OR MIST. DO NOT GET IN EYES, ON SKIN, OR ON CLOTHING. KEEP AWAY FROM ALL IGNITION SOURCES. AVOID REPEATED OR PROLONGED CONTACT. KEEP CONTAINER TIGHTLY CLOSED. WASH THOROUGHLY AFTER HANDLING. USE ONLY WITH ADEQUATE VENTILATION. 
POTENTIAL HEALTH EFFECTS:

INHALATION:

SHORT TERM EXPOSURE: MAY CAUSE BURNS. MAY CAUSE ALLERGIC REACTIONS.

ADDITIONAL EFFECTS MAY INCLUDE COUGHING, NAUSEA, VOMITING, DIFFICULTY

BREATHING, ASTHMA, LUNG CONGESTION AND KIDNEY DAMAGE. MAY ALSO CAUSE DEATH.

LONG TERM EFFECTS: IN ADDITION TO EFFECTS FROM SHORT TERM EXPOSURE,

SNEEZING, SWEATING, HAIR LOSS, WHEEZING, IRREGULAR HEARTBEAT, HEADACHE,

WEAKNESS AND KIDNEY AND LIVER DAMAGE MAY OCCUR.

SKIN CONTACT:

SHORT TERM EXPOSURE: MAY CAUSE IRRITATION, POSSIBLY SEVERE. MAY CAUSE

ALLERGIC REACTIONS. ADDITIONAL EFFECTS MAY INCLUDE BLISTERS. MAY ALSO CAUSE

DEATH .

LONG TERM EFFECTS: SAME EFFECTS AS SHORT TERM EXPOSURE.

EYE CONTACT:

SHORT TERM EXPOSURE: MAY CAUSE BURNS. ADDITIONAL EFFECTS MAY INCLUDE

BIINDNESS.

LONG TERM EFFECTS: SAME EFFECTS AS SHORT TERM EXPOSURE.

INGESTION:

SHORT TERM EXPOSURE: MAY CAUSE BURNS. ADDITIONAL EFFECTS MAY INCLUDE NAUSEA, VOMITING AND STOMACH PAIN.

LONG TERM EFFECTS: IN ADDITION TO EFFECTS FROM SHORT TERM EXPOSURE, REDNESS AND SWELLING OF THE SKIN MAY OCCUR. MAY ALSO CAUSE REPRODUCTIVE EFFECTS.

CARCINOGEN STATUS:

OSHA: $N$

NTP : N

IARC: $\mathrm{N}$

SECTION 4

FIRST AID MEASURES

INHALATION :

FIRST AID- REMOVE FROM EXPOSURE AREA TO FRESH AIR IMMEDIATELY. IF BREATHING HAS STOPPED, GIVE ARTIFICIAL RESPIRATION. MAINTAIN AIRWAY AND BLOOD PRESSURE AND ADMINISTER OXYGEN IF AVAILABLE. KEEP AFFECTED PERSON WARM AND AT REST. TREAT SYMPTOMATICALLY AND SUPPORTIVELY. ADMINISTRATION OF OXYGEN SHOULD BE PERFORMED BY QUALIFIED PERSONNEL. GET MEDICAL ATTENTION IMMED IATELY.

SKIN CONTACT:

FIRST AID- REMOVE CONTAMINATED CLOTHING AND SHOES IMMEDIATELY. WASH AFFECTED AREA WITH SOAP OR MILD DETERGENT AND LARGE AMOUNTS OF WATER UNTIL NO EVIDENCE OF CHEMICAI REMAINS (AT LEAST 15-20 MINUTES). IN CASE OF CHEMICAL BURNS, COVER AREA WITH STERILE, DRY DRESSING. BANDAGE SECURELY, BUT NOT TOO TIGHTLY. GET MEDICAL ATTENTION IMMEDIATELY.

EYE CONTACT:

FIRST AID- WASH EYES IMMEDIATELY WITH LARGE AMOUNTS OF WATER, OCCASIONALLY LIFTING UPPER AND LOWER LIDS, UNTIL NO EVIDENCE OF CHEMICAI REMAINS (AT LEAST 15-20 MINUTES). CONTINUE IRRIGATING WITH NORMAL SALINE UNTII THE PH HAS RETURNED TO NORMAI (30-60 MINUTES). COVER WITH STERILE BANDAGES. GET MEDICAL ATTENTION IMMEDIATELY. 
INGESTION :

FIRST AID- TREAT SYMPTOMATICALLY AND SUPPORTIVELY. IF PERSON IS CONSCIOUS AND ABLE TO SWALLOW, GIVE IARGE AMOUNTS OF WATER OR MILK TO DILUTE SUBSTANCE. GET MEDICAL ATTENTION IMMEDIATELY. GASTRIC LAVAGE PEREORMED BY QUALIFIED MEDICAL PERSONNEL MIGHT BE ADVISABLE IF THERE ARE NO SIGNS OF PERFORATION FROM THE INGESTION OF A CORROSIVE SUBSTANCE. IF VOMITING OCCURS, KEEP HEAD BELOW HIPS TO HELP PREVENT ASPIRATION.

NOTE TO PHYSICIAN

ANTIDOTE :

NO SPECIFIC ANTIDOTE. TREAT SYMPTOMATICALLY AND SUPPORTIVELY.

\section{SECTION 5}

FIRE AND EXPLOSION HAZARD:

DANGEROUS FIRE HAZARD WHEN EXPOSED TO HEAT OR FLAME.

VAPORS ARE HEAVIER THAN AIR AND MAY TRAVEL A CONSIDERABLE DISTANCE TO A SOURCE OF IGNITION AND FLASH BACK.

VAPOR-AIR MIXTURES ARE EXPLOSIVE ABOVE FLASH POINT.

EXTINGUISHING MEDIA:

DRY CHEMICAL, CARBON DIOXIDE, WATER SPRAY OR REGUIAR FOAM

(1990 EMERGENCY RESPONSE GUIDEBOOK, DOT P 5800.5).

FOR IAARGER FIRES, USE WATER SPRAY, FOG OR REGUILAR FOAM (1990 EMERGENCY RESPONSE GUIDEBOOK, DOT P 5800.5).

ALCOHOL FOAM

(NEPA 325M, FIRE HAZARD PROPERTIES OF FLAMMABLE LIQUIDS, GASES, AND VOLATIIE SOLIDS, 1991).

FIREFIGHTING :

MOVE CONTAINER FROM FIRE AREA IF YOU CAN DO IT WITHOUT RISK. DO NOT GET WATER INSIDE CONTAINER. APPLY COOLING WATER TO SIDES OF CONTAINERS THAT ARE EXPOSED TO FLAMES UNTIL WELI AFTER FIRE IS OUT. STAY AWAY FROM ENDS OF TANKS. WITHDRAW IMMEDIATELY IN CASE OF RISING SOUND FROM VENTING SAFETY DEVICE OR ANY DISCOLORATION OF TANK DUE TO FIRE. ISOLATE FOR 1/2 MILE IN ALL DIRECTIONS IF TANK, RAIL CAR OR TANK TRUCK IS INVOLVED IN FIRE (1990 EMERGENCY RESPONSE GUIDEBOOK, DOT P 5800,5, GUIDE PAGE 29).

EXTINGUISH ONLY IF FIOW CAN BE STOPPED. USE FLOODING QUANTITIES OF WATER AS A FOG; SOLID STREAMS MAY BE INEFFECTIVE. COOL FIRE-EXPOSED CONTAINERS WITH FLOODING AMOUNTS OF WATER APPLIED FROM AS FAR A DISTANCE AS POSSIBLE. AVOID BREATHING VAPORS; KEEP UPWIND.

FLASH POINT: $104 \mathrm{~F}(40 \mathrm{C})$

LOWER FLAMMABLE LIMIT: $2.5 \%$

UPPER FLAMMABLE IIMIT: $12.0 \%$ @ $100 \mathrm{C}$

AUTOIGNITION: $725 \mathrm{~F}$ (385 C)

FLAMMABILITY CLASS (OSHA): IC 
OHS09560

HAZARDOUS COMBUSTION PRODUCTS:

THERMAL DECOMPOSITION PRODUCTS MAY INCLUDE CORROSIVE FUMES OF AMMONIA, AND TOXIC OXIDES OF NITROGEN AND CARBON.

OCCUPATIONAL SPILL:

SHUT OFF IGNITION SOURCES. DO NOT TOUCH SPILLED MATERIAL. STOP LEAK IF YOU CAN DO IT WITHOUT RISK. USE WATER SPRAY TO REDUCE VAPORS. DO NOT GET WATER INSIDE CONTAINER. FOR SMALL SPILLS, TAKE UP WITH SAND OR OTHER ABSORBENT MATERIAL AND PLACE INTO CONTAINERS FOR LATER DISPOSAL. FOR LARGER SPILLS, DIKE FAR AHEAD OF SPILL FOR LATER DISPOSAL. NO SMOKING, FLAMES OR FLARES IN HAZARD AREA. KEEP UNNECESSARY PEOPLE AWAY; ISOLATE HAZARD AREA AND DENY ENTRY.

REPORTABLE QUANTITY (RQ): 5000 POUNDS

THE SUPERFUND AMENDMENTS AND REAUTHORIZATION ACT (SARA) SECTION 304 REQUIRES THAT A RELEASE EQUAL TO OR GREATER THAN THE REPORTABLE QUANTITY FOR THIS SUBSTANCE BE IMMEDIATELY REPORTED TO THE LOCAL EMERGENCY PLANNING COMMITTEE AND THE STATE EMERGENCY RESPONSE COMMISSION (40 CFR 355.40). IF THE RELEASE OF THIS SUBSTANCE IS REPORTABLE UNDER CERCIA SECTION 103, THE NATIONAL RESPONSE CENTER MUST BE NOTIFIED IMMEDIATELY AT (800) 424-8802 OR (202) 426-2675 IN THE METROPOLITAN WASHINGTON, D.C. AREA (40 CFR 302.6).

SOIL SPILL:

DIG A HOLDING AREA SUCH AS A PIT, POND OR LAGOON TO CONTAIN SPILL AND DIKE SURFACE FLOW USING BARRIER OF SOIL, SANDBAGS, FOAMED POLYURETHANE OR FOAMED CONCRETE. ABSORB LIQUID MASS WITH FLY ASH OR CEMENT POWDER.

USE SODIUM BISULFATE (NA-H-SO4) TO NEUTRALIZE SPILL.

AIR SPILL:

APPLY WATER SPRAY TO KNOCK DOWN AND REDUCE VAPORS. KNOCK-DOWN WATER IS CORROSIVE AND TOXIC AND SHOULD BE DIKED FOR CONTAINMENT.

WATER SPILL:

LIMIT SPILL MOTION AND DISPERSION WITH NATURAL BARRIERS OR OIL SPILL CONTROL BOOMS .

APPLY DETERGENTS, SOAPS, ALCOHOLS OR ANOTHER SURFACE ACTIVE AGENT.

APPLY UNIVERSAL GELLING AGENT TO IMMOBILIZE TRAPPED SPILL AND INCREASE EFFICIENCY OF REMOVAL.

ADD SODIUM BISULFATE.

IF DISSOLVED, AT A CONCENTRATION OF 10 PPM OR GREATER, APPLY ACTIVATED CARBON AT TEN TIMES THE AMOUNT THAT HAS BEEN SPILLED.

USE MECHANICAL DREDGES OR LIFTS TO EXTRACT IMMOBILIZED MASSES OF POLLUTION AND PRECIPITATES. 
OBSERVE ALL FEDERAL, STATE AND LOCAL REGULATIONS WHEN STORING THIS SUBSTANCE. STORE IN ACCORDANCE WITH 29 CFR 1910.106.

BONDING AND GROUNDING: SUBSTANCES WITH LOW ELECTROCONDUCTIVITY, WHICH MAY BE IGNITED BY ELECTROSTATIC SPARKS, SHOULD BE STORED IN CONTAINERS WHICH MEET THE BONDING AND GROUNDING GUIDELINES SPECIFIED IN NFPA 77-1983, RECOMMENDED PRACTICE ON STATIC ELECTRICITY.

STORE AWAY FROM INCOMPATIBLE SUBSTANCES.

THRESHOLD PLANNING QUANTITY (TPQ):

THE SUPERFUND AMENDMENTS AND REAUTHORIZATION ACT (SARA) SECTION 302 REQUIRES THAT EACH FACILITY WHERE ANY EXTREMELY HAZARDOUS SUBSTANCE IS PRESENT IN A QUANTITY EQUAL TO OR GREATER THAN THE TPQ ESTABLISHED FOR THAT SUBSTANCE NOTIFY THE STATE EMERGENCY RESPONSE COMMISSION FOR THE STATE IN WHICH IT IS LOCATED. SECTION 303 OF SARA REQUIRES THESE FACILITIES TO PARTICIPATE IN LOCAL EMERGENCY RESPONSE PLANNING (40 CFR 355.30).

KEEP IN A TIGHTLY CLOSED CONTAINER. STORE IN A COOL, DRY, VENTILATED AREA. PROTECT FROM PHYSICAL DAMAGE. STORE IN A COOL, DRY, WEIL VENTILATED AREA AWAY FROM ANY AREA WHERE FIRE HAZARD MAY BE ACUTE. OUTSIDE OR DETACHED STORAGE IS PREFERRED. INSIDE STORAGE SHOULD BE IN A STANDARD FLAMMABLE LIQUIDS STORAGE ROOM. SEPARATE FROM OXIDIZING MATERIALS. COPPER OR COPPER-BEARING ALIOYS SHOULD NOT BE USED FOR STORAGE OR HANDLING (NFPA 49, HAZARDOUS CHEMICALS DATA, 1975).

\section{SECTION $8 \quad$ EXPOSURE CONTROLS/PERSONAL PROTECTION}

EXPOSURE LIMITS:

ETHYLENEDIAMINE :

10 PPM (25 MG/M3) OSHA TWA

10 PPM (25 MG/M3) ACGIH TWA

10 PPM (25 MG/M3) NIOSH RECOMMENDED TWA

10 PPM (25 MG/M3) DFG MAK TWA;

20 PPM (50 MG/M3) DFG MAK 30 MINUTE PEAK, AVERAGE VALUE, 4 TIMES/SHIFT

MEASUREMENT METHOD: XAD-2(R) TUBE; DIMETHYLFORMAMIDE; HIGH-PRESSURE LIQUID CHROMATOGRAPHY WITH ULTRAVIOLET DETECTION; (NIOSH VOL. III \# 2540).

10,000 POUNDS SARA SECTION 302 THRESHOID PIANNING QUANTITY

5000 POUNDS SARA SECTION 304 REPORTABLE QUANTITY

5000 POUNDS CERCLA SECTION 103 REPORTABLE QUANTITY

VENTILATION:

PROCESS ENCLOSURE VENTILATION RECOMMENDED TO MEET PUBLISHED EXPOSURE LIMITS. VENTILATION EQUIPMENT MUST BE EXPLOSION-PROOF.

EYE PROTECTION:

EMPLOYEE MUST WEAR SPLASH-PROOF OR DUST-RESISTANT SAFETY GOGGLES AND A FACESHIELD TO PREVENT CONTACT WITH THIS SUBSTANCE. 
OHS09560

EMERGENCY WASH FACILITIES:

WHERE THERE IS ANY POSSIBILITY THAT AN EMPLOYEE'S EYES AND/OR SKIN MAY BE EXPOSED TO THIS SUBSTANCE, THE EMPLOYER SHOULD PROVIDE AN EYE WASH FOUNTAIN AND QUICK DRENCH SHOWER WITHIN THE IMMEDIATE WORK AREA FOR EMERGENCY USE.

CLOTHING :

EMPLOYEE MUST WEAR APPROPRIATE PROTECTIVE (IMPERVIOUS) CLOTHING AND EQUIPMENT TO PREVENT ANY POSSIBILITY OF SKIN CONTACT WITH THIS SUBSTANCE.

GLOVES :

EMPLOYEE MUST WEAR APPROPRIATE PROTECTIVE GLOVES TO PREVENT CONTACT WITH THIS SUBSTANCE .

RESPIRATOR:

THE FOLLOWING RESPIRATORS AND MAXIMUM USE CONCENTRATIONS ARE RECOMMENDATIONS BY THE U.S. DEPARTMENT OF HEALTH AND HUMAN SERVICES, NIOSH POCKET GUIDE TO CHEMICAL HAZARDS; NIOSH CRITERIA DOCUMENTS OR BY THE U.S. DEPARTMENT OF LABOR, 29 CFR 1910 SUBPART Z.

THE SPECIFIC RESPIRATOR SELECTED MUST BE BASED ON CONTAMINATION LEVELS FOUND IN THE WORK PLACE, MUST NOT EXCEED THE WORKING LIMITS OF THE RESPIRATOR AND BE JOINTLY APPROVED BY THE NATIONAL INSTITUTE FOR OCCUPATIONAL SAFETY AND HEALTH AND THE MINE SAFETY AND HEALTH ADMINISTRATION (NIOSH-MSHA).

ETHYLENEDIAMINE :

250 PPM- ANY SUPPLIED-AIR RESPIRATOR OPERATED IN A CONTINUOUS-FLOW MODE. ANY POWERED, AIR-PURIFYING RESPIRATOR WITH CARTRIDGE(S) PROVIDING PROTECTION AGAINST ETHYLENEDIAMINE.

500 PPM- ANY CHEMICAL CARTRIDGE RESPIRATOR WITH A FULI FACEPIECE AND CARTRIDGE (S) PROVIDING PROTECTION AGAINST ETHYLENEDIAMINE.. ANY AIR-PURIFYING, FULL-FACEPIECE RESPIRATOR (GAS MASK) WITH A CHIN-STYLE, FRONT- OR BACK- MOUNTED CANISTER PROVIDING PROTECTION AGAINST ETHYLENEDIAMINE.

ANY SELF-CONTAINED BREATHING APPARATUS WITH A FULL FACEPIECE. ANY SUPPLIED-AIR RESPIRATOR WITH A FULL FACEPIECE.

2000 PPM- ANY SUPPLIED-AIR RESPIRATOR THAT HAS A FULL FACEPIECE ANDIS OPERATED IN A PRESSURE-DEMAND OR OTHER POSITIVE- PRESSURE MODE.

ESCAPE- ANY AIR-PURIFYING, FULL FACEPIECE RESPIRATOR (GAS MASK) WITH A CHIN-SYYLE, FRONT- OR BACK-MOUNTED CANISTER PROVIDING PROTECTION AGAINST ETHYLENEDIAMINE.

ANY APPROPRIATE ESCAPE-TYPE, SELF-CONTAINED BREATHING APPARATUS.

FOR FIREFIGHTING AND OTHER IMMEDIATELY DANGEROUS TO LIFE OR HEALTH CONDITIONS:

ANY SELF-CONTAINED BREATHING APPARATUS THAT HAS A FULL FACEPIECE AND IS OPERATED IN A PRESSURE-DEMAND OR OTHER POSITIVE-PRESSURE MODE.

ANY SUPPLIED-AIR RESPIRATOR THAT HAS A FULI FACEPIECE AND IS OPERATED IN A PRESSURE-DEMAND OR OTHER POSITIVE-PRESSURE MODE IN COMBINATION WITH AN AUXILIARY SELF-CONTAINED BREATHING APPARATUS OPERATED IN PRESSURE-DEMAND OR OTHER POSITIVE-PRESSURE MODE. 


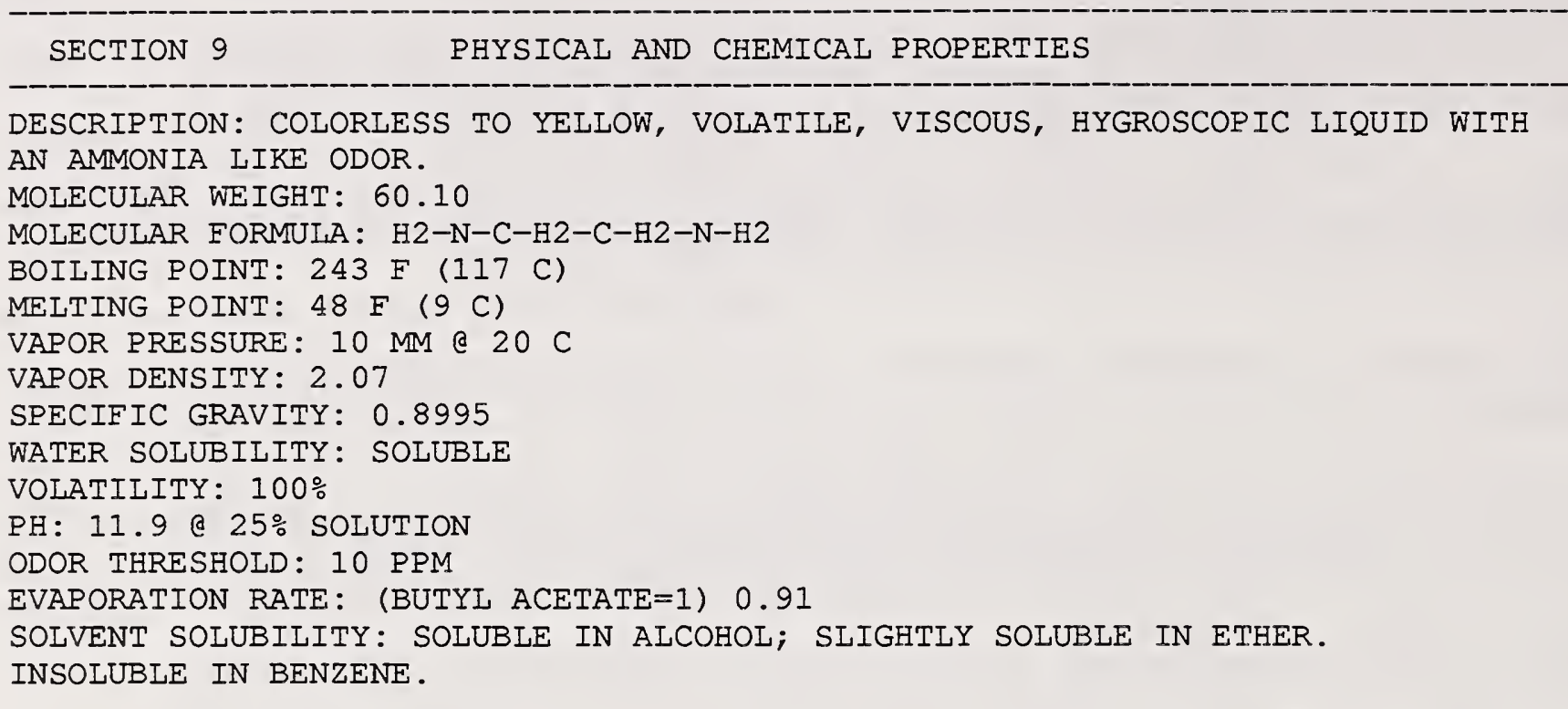

SECTION $10 \quad$ STABILITY AND REACTIVITY

REACTIVITY:

STABLE UNDER NORMAL TEMPERATURES AND PRESSURES.

CONDITIONS TO AVOID:

AVOID CONTACT WITH HEAT, SPARKS, FIAMES OR OTHER IGNITION SOURCES. VAPORS MAY BE EXPLOSIVE. MATERIAL IS CORROSIVE; AVOID CONTACT WITH SKIN OR EYES. DO NOT ALLOW CONTAMINATION OF WATER SOURCES.

INCOMPATIBILITIES:

ETHYLENED IAMINE :

ACETIC ACID: TEMPERATURE AND PRESSURE INCREASE IN A CLOSED CONTAINER.

ACETIC ANHYDRIDE: TEMPERATURE AND PRESSURE INCREASE IN A CLOSED CONTAINER.

ACIDS (STRONG): FIRE AND EXPLOSION HAZARD.

ACROLEIN: TEMPERATURE AND PRESSURE INCREASE IN A CLOSED CONTAINER.

ACRYIIC ACID: TEMPERATURE AND PRESSURE INCREASE IN A CLOSED CONTAINER.

ACRYLONITRILE: TEMPERATURE AND PRESSURE INCREASE IN A CLOSED CONTAINER.

ALLYL CHLORIDE: TEMPERATURE AND PRESSURE INCREASE IN A CLOSED CONTAINER.

ALUMINUM: MAY BE CORROSIVE.

CARBON DISULFIDE: TEMPERATURE AND PRESSURE INCREASE IN A CLOSED CONTAINER.

CELLULOSE NITRATE: IGNITES SPONTANEOUSLY.

CHLORINATED HYDROCARBONS: VIOLENT REACTION.

CHLOROSULFONIC ACID: TEMPERATURE AND PRESSURE INCREASE IN A CLOSED

CONTAINER.

DIISOPROPYLPEROXYDICARBONATE: SPONTANEOUS DECOMPOSITION.

EPICHLOROHYDRIN: TEMPERATURE AND PRESSURE INCREASE IN A CLOSED CONTAINER.

ETHYLENE CHLOROHYDRIN: TEMPERATURE AND PRESSURE INCREASE IN A CLOSED CONTAINER.

HYDROCHLORIC ACID: TEMPERATURE AND PRESSURE INCREASE IN A CIOSED CONTAINER. MESITYL OXIDE: TEMPERATURE AND PRESSURE INCREASE IN A CLOSED CONTAINER. 
OHS09560

NITRIC ACID: TEMPERATURE AND PRESSURE INCREASE IN A CLOSED CONTAINER. NITROMETHANE: INCREASED SENSITIVITY TOWARD DETONATION.

OLEUM: TEMPERATURE AND PRESSURE INCREASE IN A CLOSED CONTAINER. OXIDIZERS (STRONG): FIRE AND EXPIOSION HAZARD.

BETA-PROPIOLACTONE: TEMPERATURE AND PRESSURE INCREASE IN A CLOSED CONTAINER. SILVER PERCHLORATE: EXPLOSIVE REACTION.

SULFURIC ACID: TEMPERATURE AND PRESSURE INCREASE IN A CLOSED CONTAINER. VINYL ACETATE: TEMPERATURE AND PRESSURE INCREASE IN A CLOSED CONTAINER. ZINC: MAY BE CORROSIVE.

HAZARDOUS DECOMPOSITION:

THERMAL DECOMPOSITION PRODUCTS MAY INCLUDE CORROSIVE FUMES OF AMMONIA, AND TOXIC OXIDES OF NITROGEN AND CARBON.

POLYMERIZATION :

HAZARDOUS POLYMERIZATION HAS NOT BEEN REPORTED TO OCCUR UNDER NORMAL TEMPERATURES AND PRESSURES.

SECTION 11

TOXICOLOGY INEORMATION

ETHYLENEDIAMINE:

IRRITATION DATA: 450 MG OPEN SKIN-RABBIT MODERATE; $10 \mathrm{MG} / 24$ HOURS OPEN SKIN-RABBIT SEVERE; 750 UG EYE-RABBIT SEVERE; 750 UG/24 HOURS EYE-RABBIT SEVERE.

TOXICITY DATA: 200 PPM INHALATION-HUMAN TCLO; 300 MG/M3 INHALATION-MOUSE LC50; 4000 PPM/8 HOURS INHALATION-RAT LC100 (AMIHBC); 4000 PPM/8 HOURS

INHALATION-RAT LCLO; $730 \mathrm{MG/KG} \mathrm{SKIN-RABBIT} \mathrm{LD50;} 500 \mathrm{MG/KG} \mathrm{ORAL-RAT} \mathrm{LD50;}$

$470 \mathrm{MG} / \mathrm{KG}$ ORAL-GUINEA PIG LD50; $500 \mathrm{MG} / \mathrm{KG}$ SUBCUTANEOUS-RABBIT LDLO;

$300 \mathrm{MG} / \mathrm{KG}$ SUBCUTANEOUS-RAT LD50; $100 \mathrm{MG/KG} \mathrm{INTRAVENOUS-DOG} \mathrm{LDLO;}$

$76 \mathrm{MG} /$ KG INTRAPERITONEAL-RAT LD50; $200 \mathrm{MG/KG} \mathrm{INTRAPERITONEAL-MOUSE} \mathrm{LD50;}$

MUTAGENIC DATA (RTECS); REPRODUCTIVE EFFECTS DATA (RTECS).

CARCINOGEN STATUS: NONE.

LOCAL EFFECTS: CORROSIVE- INHALATION, SKIN, EYE, INGESTION.

ACUTE TOXICITY LEVEL: HIGHLY TOXIC BY INHALATION; TOXIC BY DERMAL ABSORPTION AND INGESTION.

TARGET EFFECTS: SENSITIZER- RESPIRATORY, SKIN. POISONING MAY AFFECT THE LUNGS, LIVER, AND KIDNEYS.

AT INCREASED RISK FROM EXPOSURE: PERSONS WITH PREEXISTING ASTHMA OR ALLERGIES. ADDITIONAL DATA: CROSS-SENSITIZATION MAY OCCUR WITH OTHER ETHYLENEAMINES, SOME POLYAMINES, AND WITH HYDRAZINE AND PIPERAZINE ANTIHISTAMINES.

HEALTH EFFECTS

INHALATION :

ETHYLENEDIAMINE :

CORROSIVE/SENSITIZER/HIGHLY TOXIC.

2000 PPM IMMEDIATELY DANGEROUS TO LIFE OR HEALTH.

ACUTE EXPOSURE- HUMAN EXPOSURE TO 200 PPM FOR 5-10 SECONDS CAUSED FACIAL TINGLING AND SLIGHT NASAL IRRITATION; 400 PPM CAUSED INTOLERABLE NASAL IRRITATION. OTHER SYMPTOMS MAY INCLUDE RESPIRATORY TRACT IRRITATION, COUGH, DYSPNEA, VOMITING, NAUSEA AND PULMONARY EDEMA. PULMONARY SENSITIZATION, MANIFESTED BY ASTHMATIC BREATHING, MAY OCCUR IN PREVIOUSLY EXPOSED PERSONS. RATS EXPOSED TO 4000 PPM FOR 8 HOURS DIED FROM KIDNEY DAMAGE. 
CHRONIC EXPOSURE- PROLONGED OR REPEATED EXPOSURE TO NON-IRRITATING LEVELS MAY RESULT IN PULMONARY SENSITIZATION WITH BRONCHIAI ASTHMA. CHRONIC BRONCHITIS HAS ALSO BEEN REPORTED. SYMPTOMS MAY INCLUDE EOSINOPHILIA, WHEEZING, CHEST TIGHTNESS, COUGHING DYSPNEA, SNEEZING, NASAL DISCHARGE, SWEATING, HEADACHES, MALAISE, AND TACHYCARDIA. EXPOSURE TO 484 PPM FOR 20 DAYS CAUSED DEPILATION AND LUNG, KIDNEY AND LIVER DAMAGE, AND DEATH IN RATS.

SKIN CONTACT:

ETHYLENEDIAMINE :

CORROSIVE/SENSITIZER/TOXIC.

ACUTE EXPOSURE- DIRECT CONTACT WITH AQUEOUS SOLUTIONS MAY CAUSE SEVERE IRRITATION. UNDILUTED LIQUID MAY CAUSE BURNS. BLISTERING MAY OCCUR AND BE PARTLY DUE TO SENSITIZATION IN PREVIOUSLY EXPOSED PERSONS. ANIMAL STUDIES INDICATE FATAL AMOUNTS MAY BE ABSORBED THROUGH INTACT SKIN. SKIN ABSORPTION IS ENHANCED BY TISSUE DAMAGE.

CHRONIC EXPOSURE- REPEATED OR PROLONGED EXPOSURE MAY CAUSE DERMATITIS DUE EITHER TO IRRITATION OR SENSITIZATION. SENSITIZATION IS MORE LIKELY TO OCCUR WHEN THE SKIN IS DAMAGED.

EYE CONTACT:

ETHYLENEDIAMINE :

CORROSIVE.

ACUTE EXPOSURE- LOW VAPOR CONCENTRATIONS MAY CAUSE SOME BLURRING OF VISION AND HALOES AROUND OBJECTS. HIGH VAPOR CONCENTRATIONS MAY CAUSE ACUTE PAIN AND SEVERE IRRITATION. THE LIQUID MAY CAUSE BURNS, CORNEAI, DESTRUCTION, AND BLINDNESS. AN AQUEOUS 15\% SOLUTION CAUSED SERIOUS CORNEAL DAMAGE TO RABBIT EYES; A 5\% SOLUTION CAUSED PARTIAL CORNEAL OPACITY.

CHRONIC EXPOSURE- EFFECTS DEPEND ON CONCENTRATION AND DURATION OF EXPOSURE. REPEATED OR PROLONGED CONTACT WITH CORROSIVE SUBSTANCES MAY RESULT IN CONJUNCTIVITIS OR EFFECTS AS IN ACUTE EXPOSURE.

INGESTION :

ETHYLENEDIAMINE:

CORROSIVE/TOXIC.

ACUTE EXPOSURE- INGESTION MAY CAUSE BURNS OF THE MOUTH AND THROAT, ABDOMINAL PAIN, NAUSEA, AND VOMITING. THE REPORTED LETHAL DOSE IN RATS WAS $500 \mathrm{MG} / \mathrm{KG}$; THE SYMPTOMS WERE NOT REPORTED.

CHRONIC EXPOSURE- THERAPEUTIC USE HAS RESULTED IN SEVERE EXFOLIATIVE DERMATITIS. REPRODUCTIVE EFFECTS HAVE BEEN REPORTED IN ANIMALS. DEPENDING ON THE CONCENTRATIONS, REPEATED INGESTION OF CORROSIVE SUBSTANCES MAY RESULT IN EFFECTS AS WITH ACUTE INGESTION.

SECTION 12 ECOLOGICAL INFORMATION

ENVIRONMENTAL IMPACT RATING $(0-4)$ : NO DATA AVAILABLE

ACUTE AQUATIC TOXICITY: NO DATA AVAILABLE

DEGRADABILITY: NO DATA AVAILABLE

LOG BIOCONCENTRATION FACTOR (BCF): NO DATA AVAILABLE 
OHS09560

LOG OCTANOL/WATER PARTITION COEFFICIENT: NO DATA AVAILABLE

SECTION 13 DISPOSAL INFORMATION

OBSERVE ALL FEDERAL, STATE AND LOCAL REGULATIONS WHEN DISPOSING OF THIS SUBSTANCE .

DISPOSAL MUST BE IN ACCORDANCE WITH STANDARDS APPLICABLE TO GENERATORS OF HAZARDOUS WASTE, 40 CFR 262. EPA HAZARDOUS WASTE NUMBER D001.

100 POUND CERCLA SECTION 103 REPORTABLE QUANTITY.

SECTION 14

DEPARTMENT OF TRANSPORTATION HAZARD CLASSIFICATION 49-CFR 172.101: CORROSIVE MATERIAL

DEPARTMENT OF TRANSPORTATION LABELING REQUIREMENTS 49-CFR 172.101 AND SUBPART E:

CORROSIVE

DEPARTMENT OF TRANSPORTATION PACKAGING REQUIREMENTS: 49-CFR 173.245

EXCEPTIONS: 49-CFR 173.244

FINAL RULE ON HAZARDOUS MATERIALS REGULATIONS (HMR, 49 CFR PARTS 171-180), DOCKET NUMBERS HM-181, HM-181A, HM-181B, HM-181C, HM-181D AND HM-204.

EFFECTIVE DATE OCTOBER 1, 1991. HOWEVER, COMPLIANCE WITH THE REGULATIONS IS

AUTHORIZED ON AND AFTER JANUARY 1, 1991. (55 FR 52402, 12/21/90)

EXCEPT FOR EXPLOSIVES, INHALATION HAZARDS, AND INFECTIOUS SUBSTANCES, THE EFFECTIVE DATE FOR HAZARD COMMUNICATION REQUIREMENTS IS EXTENDED TO

OCTOBER 1, 1993. (56 FR 47158, 09/18/91)

U.S. DEPARTMENT OF TRANSPORTATION SHIPPING NAME-ID NUMBER, 49 CFR 172.101:

ETHYLENEDIAMINE-UN 1604

U.S. DEPARTMENT OF TRANSPORTATION HAZARD CLASS OR DIVISION, 49 CFR 172.101:

8 - CORROSIVE MATERIAL

U.S. DEPARTMENT OF TRANSPORTATION PACKING GROUP, 49 CFR 172.101:

PG II

U.S. DEPARTMENT OF TRANSPORTATION LABELING REQUIREMENTS, 49 CFR 172.101

AND SUBPART E:

CORROSIVE, FLAMMABLE LIQUID

U.S. DEPARTMENT OF TRANSPORTATION PACKAGING AUTHORIZATIONS:

EXCEPTIONS: 49 CFR 173.154

NON-BULK PACKAGING: 49 CFR 173.202

BULK PACKAGING: 49 CFR 173.243

U.S. DEPARTMENT OF TRANSPORTATION QUANTITY LIMITATIONS 49 CFR 172.101: 
PASSENGER AIRCRAFT OR RAILCAR: $1 \mathrm{~L}$ CARGO AIRCRAFT ONLY: $30 \mathrm{I}$

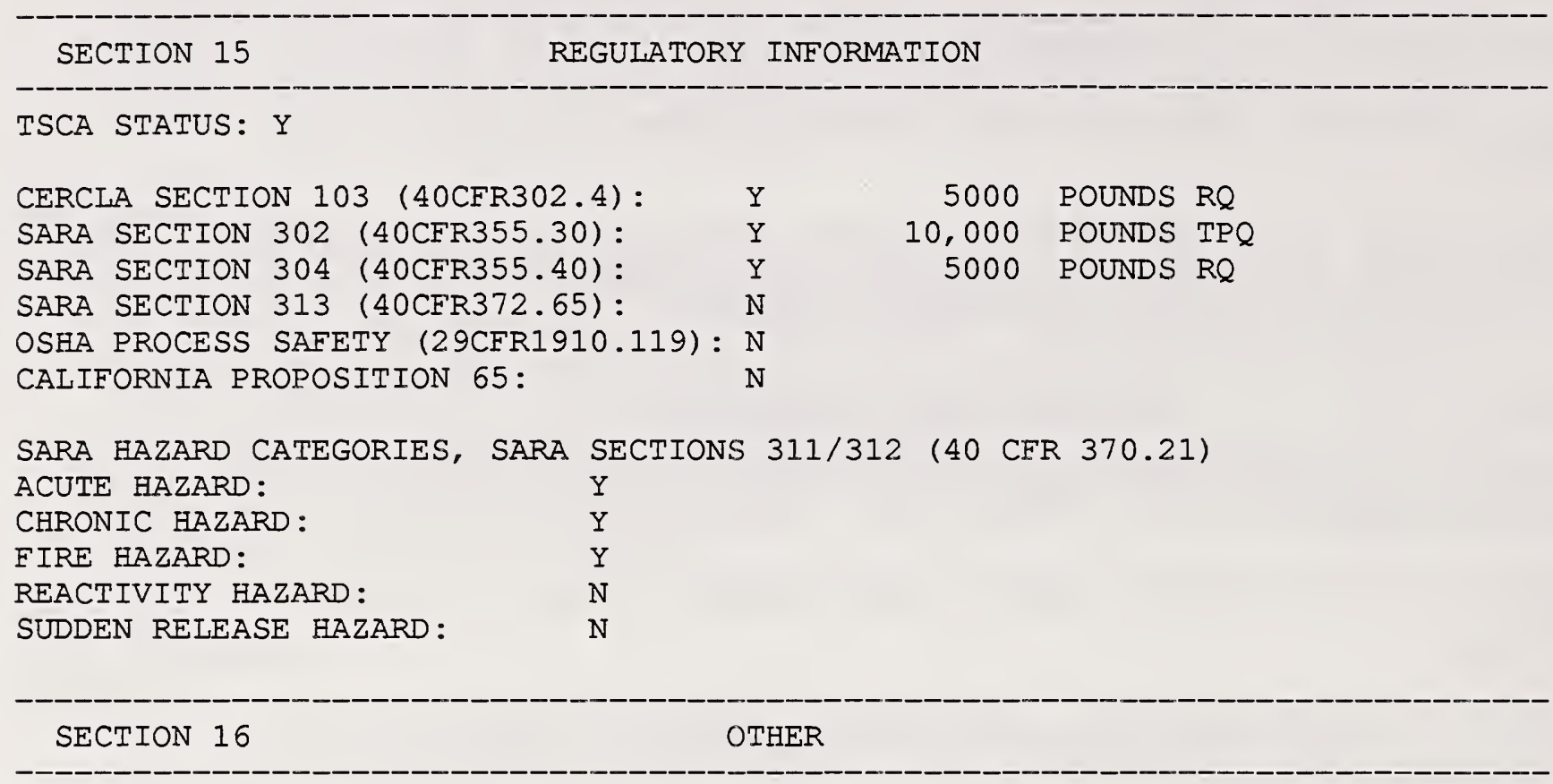

\section{COPYRIGHT 1993 OCCUPATIONAL HEALTH SERVICES, INC.. ALI RIGHTS RESERVED. \\ Licensed to: National Institute of Standards and Technology \\ To make unlimited paper copies for internal distribution and use only. Permission received 11/22/93 from Richard Cohen, V.P. at OHS, Inc. to distribute this MSDS to the MOSIS community. Permission received 1/21/94 from Richard Cohen, V.P. at OHS, Inc. to include this MSDS in a NIST Internal Report.}

The above MSDS (Material Safety Data Sheet) was prepared by Occupational Health Services, Inc. from data received from various sources. OHS, Inc. did not perform the tests, therefore this MSDS is meant solely as a guide and the National Institute of Standards and Technology, the Information Sciences Institute, the George Washington University, and Occupational Health Services, Inc., are not liable under any circumstances for any accidents or inadequate information associated with the substance for which this MSDS was written. 
APPENDIX B. THE MSDS FOR THE SUBSTANCE CATECHOL

OHSO 4360

$\begin{array}{lll}\text { SECTION } 1 & \text { CHEMICAI PRODUCTS \& COMPANY IDENTIFICATION } \\ \text { OCCUPATIONAI HEALTH SERVICES, INC. } & \text { FOR EMERGENCY SOURCE INEORMATION } \\ 11 \text { WEST 42ND STREET, I2TH FLOOR } & \text { CONTACT: } 1-615-366-2000\end{array}$

NEW YORK, NEW YORK 10036

$1-800-445-M S D S \quad(1-800-445-6737)$ OR

$1-212-789-3535$

CAS NUMBER: 120-80-9

RTECS NUMBER: UX1050000

SUBSTANCE: CATECHOL

TRADE NAMES/SYNONYMS:

1,2-DIHYDROXYBENZENE; 1, 2-BENZENEDIOI; 2-HYDROXYPHENOI; O-HYDROXYPHENOI; O-HYDROQUINONE; O-DIOXYBENZENE; O-DIHYDROXYBENZENE; BENZENE, O-DIHYDROXY-; O-BENZENEDIOI; O-PHENYIENEDIOL; PYROCATECHOL; PYROCATECHIN;

PYROCATECHINIC ACID; OXYPHENIC ACID; PYROCATECHINE; PHTHALHYDROQUINONE;

C.I. 76500; C6H6O2; OHSO4360

CHEMICAL FAMIIY:

HYDROXYI, AROMATIC

CREATION DATE: 12/21/84

REVISION DATE: 07/14/93

SECTION 2

COMPOSITION/INFORMATION ON INGREDIENTS

COMPONENT : CATECHOL

CAS NUMBER: $120-80-9$

PERCENTAGE : 100

OTHER CONTAMINANTS: NONE

SECTION 3

HAZARDS IDENTIFICATION

CERCLA RATINGS (SCALE 0-3): HEALTH=3 FIRE=1 REACTIVITY=0 PERSISTENCE=1 NFPA RATINGS (SCALE 0-4): HEALTH=2 FIRE=1 REACTIVITY=0

EMERGENCY OVERVIEW:

CATECHOL IS A COLORLESS TO WHITE OR BROWN SOLID WITH AN UNUSUAL ODOR.

HARMFUL IF ABSORBED THROUGH SKIN. HARMFUL IF SWALLOWED. CAUSES RESPIRATORY

TRACT, SKIN AND EYE BURNS. CAUSES SEVERE BURNS TO MUCOUS MEMBRANES. MAY CAUSE

ALLERGIC SKIN REACTION. MAY FORM FLAMMABIE OR EXPLOSIVE DUST-AIR MIXTURES.

DO NOT BREATHE DUST. DO NOT GET IN EYES, ON SKIN, OR ON CIOTHING. KEEP AWAY

FROM ALI IGNITION SOURCES. AVOID REPEATED OR PROIONGED CONTACT. KEEP CONTAINER TIGHTLY CLOSED. AVOID DISPERSION OF DUST. WASH THOROUGHLY AFTER HANDIING. USE ONIY WITH ADEQUATE VENTILATION.

POTENTIAL HEALTH EFFECTS: 
INHALATION :

SHORT TERM EXPOSURE: MAY CAUSE IRRITATION, POSSIBLY SEVERE. ADDITIONAL EFFECTS MAY INCLUDE COUGHING, DIFFICULTY BREATHING AND TWITCHING. LONG TERM EFFECTS: SAME EFFECTS AS SHORT TERM EXPOSURE.

SKIN CONTACT:

SHORT TERM EXPOSURE: MAY CAUSE IRRITATION, POSSIBLY SEVERE. MAY CAUSE

ALLERGIC REACTIONS. ADDITIONAL EFFECTS MAY INCLUDE SWEATING, YELLOWING OF THE SKIN AND EYES, NAUSEA, VOMITING, DIARRHEA, STOMACH PAIN, INABILITY TO URINATE, DIFFICULTY BREATHING, HYPERACTIVITY, BLUISH SKIN COLOR, LUNG DAMAGE, BLOOD DISORDERS, CONVULSIONS, UNCONSCIOUSNESS AND COMA. MAY ALSO CAUSE DEATH.

LONG TERM EFFECTS: SAME EFFECTS AS SHORT TERM EXPOSURE.

EYE CONTACT:

SHORT TERM EXPOSURE: MAY CAUSE IRRITATION, POSSIBLY SEVERE. ADDITIONAL EFFECTS MAY INCLUDE BLURRED VISION.

LONG TERM EFFECTS: SAME EFFECTS AS SHORT TERM EXPOSURE.

INGESTION :

SHORT TERM EXPOSURE: MAY CAUSE IRRITATION, POSSIBLY SEVERE. MAY CAUSE

EFFECTS AS REPORTED IN OTHER EXPOSURES. ADDITIONAL EFFECTS MAY INCLUDE VOMITING, DIARRHEA AND STOMACH PAIN.

LONG TERM EFFECTS: MAY CAUSE TUMORS.

CARCINOGEN STATUS:

OSHA: $N$

NTP : N

IARC: $\mathrm{N}$

SECTION 4

FIRST AID MEASURES

INHALATION :

FIRST AID- REMOVE FROM EXPOSURE AREA TO FRESH AIR IMMEDIATELY. IF BREATHING HAS STOPPED, GIVE ARTIFICIAL RESPIRATION. MAINTAIN AIRWAY AND BLOOD PRESSURE AND ADMINISTER OXYGEN IF AVAILABLE. KEEP AFFECTED PERSON WARM AND AT REST. TREAT SYMPTOMATICALLY AND SUPPORTIVELY. ADMINISTRATION OF OXYGEN SHOULD BE PERFORMED BY QUALIFIED PERSONNEL. GET MEDICAL ATTENTION IMMEDIATELY.

SKIN CONTACT:

FIRST AID- REMOVE CONTAMINATED CLOTHING AND SHOES IMMEDIATELY. WASH AFFECTED AREA WITH SOAP OR MILD DETERGENT AND LARGE AMOUNTS OF WATER UNTIL NO EVIDENCE OF CHEMICAL REMAINS (AT LEAST 15-20 MINUTES). IN CASE OF CHEMICAL BURNS, COVER AREA WITH STERILE, DRY DRESSING. BANDAGE SECURELY, BUT NOT TOO TIGHTLY. GET MEDICAL ATTENTION IMMEDIATELY.

EYE CONTACT:

FIRST AID- WASH EYES IMMEDIATELY WITH LARGE AMOUNTS OF WATER, OCCASIONALLY LIFTING UPPER AND LOWER LIDS, UNTIL NO EVIDENCE OF CHEMICAL REMAINS (AT LEAST 15-20 MINUTES). CONTINUE IRRIGATING WITH NORMAL SALINE UNTIL THE PH HAS RETURNED TO NORMAL (30-60 MINUTES). COVER WITH STERILE BANDAGES. GET MEDICAL ATTENTION IMMEDIATELY.

INGESTION : 
OHSO 4360

FIRST AID- IF VICTIM IS CONSCIOUS, AND IF CORROSIVE INJURY IS ABSENT, REMOVE POISON BY GASTRIC LAVVAGE OR EMESIS. ACTIVATED CHARCOAL IS USEFUL. FOLLOW WITH $240 \mathrm{ML}$ OF MILK. GASTRIC LAVAGE AND EMESIS ARE NOT TO BE USED IN THE PRESENCE OF ESOPHAGEAL INJURY (DREISBACH, HANDBOOK OF POISONING, 12TH ED.). GASTRIC LAVAGE SHOULD BE PERFORMED BY QUALIFIED MEDICAL PERSONNEL. GET MEDICAL ATTENTION IMMEDIATELY.

NOTE TO PHYSICIAN

ANTIDOTE:

NO SPECIFIC ANTIDOTE. TREAT SYMPTOMATICALLY AND SUPPORTIVELY.

\section{SECTION 5}

FIRE FIGHTING MEASURES

FIRE AND EXPLOSION HAZARD:

SLIGHT FIRE HAZARD WHEN EXPOSED TO HEAT OR FLAME.

DUST-AIR MIXTURES MAY IGNITE OR EXPLODE.

EXTINGUISHING MEDIA:

DRY CHEMICAL, CARBON DIOXIDE, WATER SPRAY OR REGULAR FOAM

(1990 EMERGENCY RESPONSE GUIDEBOOK, DOT P 5800.5).

FOR LARGER FIRES, USE WATER SPRAY, FOG OR REGULAR FOAM

(1990 EMERGENCY RESPONSE GUIDEBOOK, DOT P 5800.5).

FIREF IGHTING :

MOVE CONTAINER FROM FIRE AREA IF YOU CAN DO IT WITHOUT RISK (1990 EMERGENCY

RESPONSE GUIDEBOOK, DOT P 5800.5, GUIDE PAGE 53).

EXTINGUISH USING AGENT SUITABLE FOR TYPE OF SURROUNDING FIRE. AVOID BREATHING VAPORS AND DUSTS. KEEP UPWIND.

FLASH POINT: $261 \mathrm{~F}(127 \mathrm{C})(\mathrm{CC})$

HAZARDOUS COMBUSTION PRODUCTS:

THERMAL DECOMPOSITION MAY RELEASE ACRID SMOKE AND IRRITATING FUMES.

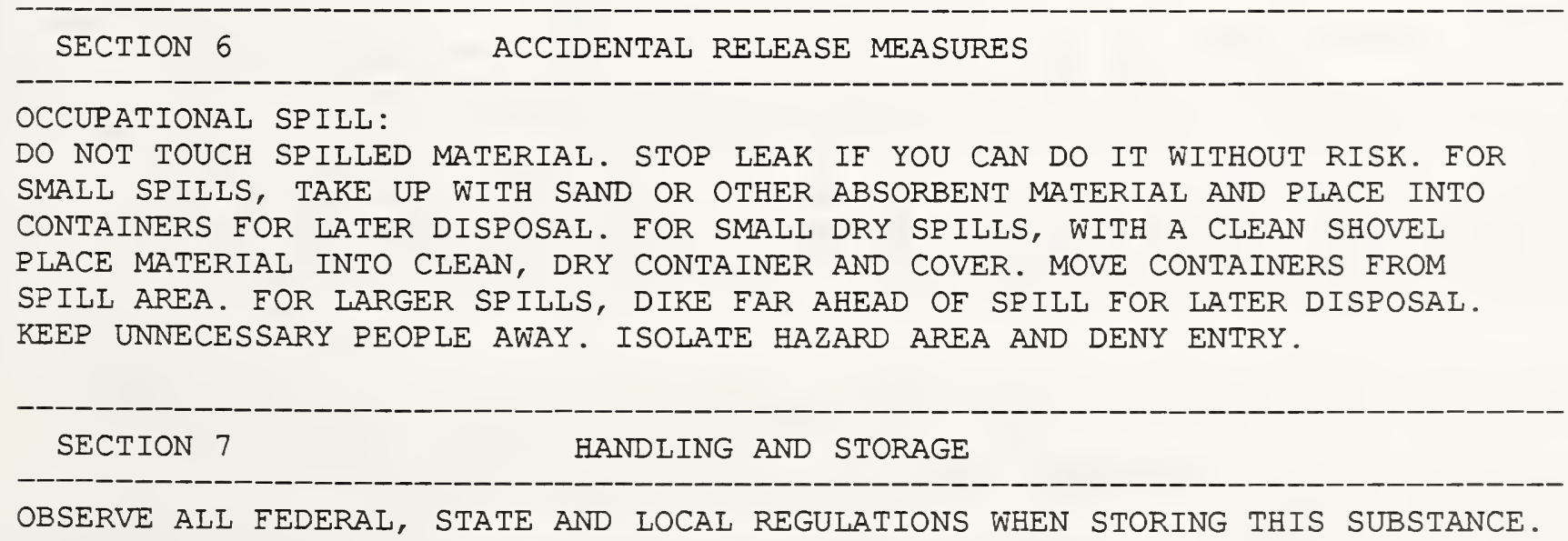


STORE AWAY FROM INCOMPATIBLE SUBSTANCES.

EXCTION 8
EXPOSURE LIMITS:
CATECHOL:
5 PPM (23 MG/M3) OSHA TWA (SKIN)
5 PPM (23 MG/M3) ACGIH TWA (SKIN)
5 PPM (23 MG/M3) NIOSH RECOMMENDED TWA (SKIN)
SUBJECT TO SARA SECTION 313 ANNUAL TOXIC CHEMICAL RELEASE REPORTING
* OSHA REVOKED THE FINAL RULE LIMITS OF JANUARY 19, 1989 IN RESPONSE TO THE
IITH CIRCUIT COURT OF APPEALS DECISION (AFL-CIO V. OSHA) EFFECTIVE
JUNE 30, 1993. SEE 29 CFR 1910.1000 (58 FR 35338)**

VENTILATION :

PROVIDE LOCAL EXHAUST OR PROCESS ENCLOSURE VENTILATION TO MEET THE PUBLISHED EXPOSURE LIMITS. VENTILATION EQUIPMENT MUST BE EXPLOSION-PROOF.

EYE PROTECTION:

EMPLOYEE MUST WEAR SPLASH-PROOF OR DUST-RESISTANT SAFETY GOGGLES AND A FACESHIELD TO PREVENT CONTACT WITH THIS SUBSTANCE.

EMERGENCY WASH FACILITIES:

WHERE THERE IS ANY POSSIBILITY THAT AN EMPLOYEE'S EYES AND/OR SKIN MAY BE EXPOSED TO THIS SUBSTANCE, THE EMPLOYER SHOULD PROVIDE AN EYE WASH FOUNTAIN AND QUICK DRENCH SHOWER WITHIN THE IMMEDIATE WORK AREA FOR EMERGENCY USE.

CLOTHING :

EMPLOYEE MUST WEAR APPROPRIATE PROTECTIVE (IMPERVIOUS) CLOTHING AND EQUIPMENT TO PREVENT ANY POSSIBIIITY OF SKIN CONTACT WITH THIS SUBSTANCE.

GLOVES:

EMPLOYEE MUST WEAR APPROPRIATE PROTECTIVE GLOVES TO PREVENT CONTACT WITH THIS SUBSTANCE.

RESPIRATOR:

THE FOLLOWING RESPIRATORS ARE RECOMMENDED BASED ON INFORMATION FOUND IN THE PHYSICAL DATA, TOXICITY AND HEALTH EFFECTS SECTIONS. THEY ARE RANKED IN ORDER FROM MINIMUM TO MAXIMUM RESPIRATORY PROTECTION.

THE SPECIFIC RESPIRATOR SELECTED MUST BE BASED ON CONTAMINATION LEVELS FOUND IN THE WORK PLACE, MUST BE BASED ON THE SPECIFIC OPERATION, MUST NOT EXCEED THE WORKING LIMITS OF THE RESPIRATOR AND MUST BE JOINTLY APPROVED BY THE NATIONAL INSTITUTE FOR OCCUPATIONAL SAFETY AND HEALTH AND THE MINE SAFETY AND HEALTH ADMINISTRATION (NIOSH-MSHA).

ANY DUST AND MIST RESPIRATOR WITH A FULL FACEPIECE.

ANY AIR-PURIFYING FULL FACEPIECE RESPIRATOR WITH A HIGH-EFFICIENCY PARTICULATE FILTER. 
ANY POWERED AIR-PURIFYING RESPIRATOR WITH A TIGHT-FITTING FACEPIECE AND HIGH-EFFICIENCY PARTICULATE FILTER.

ANY TYPE ' $C$ ' SUPPLIED-AIR RESPIRATOR WITH A FULL FACEPIECE OPERATED IN PRESSURE-DEMAND OR OTHER POSITIVE PRESSURE MODE OR WITH A FULL FACEPIECE, HELMET OR HOOD OPERATED IN CONTINUOUS-FLOW MODE.

ANY SELF-CONTAINED BREATHING APPARATUS WITH A FULL FACEPIECE OPERATED IN PRESSURE-DEMAND OR OTHER POSITIVE PRESSURE MODE.

FOR FIREFIGHTING AND OTHER IMMEDIATELY DANGEROUS TO LIFE OR HEALTH CONDITIONS:

ANY SELF-CONTAINED BREATHING APPARATUS THAT HAS A FULL FACEPIECE AND IS OPERATED IN A PRESSURE-DEMAND OR OTHER POSITIVE-PRESSURE MODE.

ANY SUPPLIED-AIR RESPIRATOR THAT HAS A FULL FACEPIECE AND IS OPERATED IN A PRESSURE-DEMAND OR OTHER POSITIVE-PRESSURE MODE IN COMBINATION WITH AN AUXILIARY SELF-CONTAINED BREATHING APPARATUS OPERATED IN PRESSURE-DEMAND OR OTHER POSITIVE-PRESSURE MODE.

DESCRIPTION: COLORLESS TO WHITE CRYSTALLINE SOLID WITH A PHENOLIC ODOR AND A SWEET AND BITTER TASTE; MAY DISCOLOR TO BROWN ON EXPOSURE TO AIR, LIGHT, AND ESPECIALLY IN THE PRESENCE OF MOISTURE.

MOLECULAR WEIGHT: 110.11

MOLECULAR FORMULA: $\mathrm{H}-\mathrm{O}-\mathrm{C} 6-\mathrm{H} 4-\mathrm{O}-\mathrm{H}$

BOILING POINT: $473 \mathrm{~F}(245 \mathrm{C})$ @ $750 \mathrm{MMHG}$

MELTING POINT: $221 \mathrm{~F}(105 \mathrm{C})$

VAPOR PRESSURE: 5 MMHG \& $104 \mathrm{C}$

VAPOR DENSITY: 3.79

SPECIFIC GRAVITY: 1.1493

WATER SOLUBILITY: SOLUBLE

SOLVENT SOLUBILITY: SOLUBLE IN ALCOHOL, ETHER, PYRIDINE, ACETONE, BENZENE, CHLOROFORM, CARBON TETRACHLORIDE AND AQUEOUS ALKALINE SOLUTIONS.

SECTION $10 \quad$ STABILITY AND REACTIVITY

REACTIVITY:

STABLE UNDER NORMAL TEMPERATURES AND PRESSURES.

CONDITIONS TO AVOID:

MAY BURN BUT DOES NOT IGNITE READILY. PREVENT DISPERSION OF DUST IN AIR. DO NOT ALLOW SPILLED MATERIAL TO CONTAMINATE WATER SOURCES.

INCOMPATIBILITIES:

CATECHOL:

NITRIC ACID: MAY CAUSE HYPERGOLIC REACTION.

OXIDIZERS (STRONG): FIRE AND EXPLOSION HAZARD.

HAZARDOUS DECOMPOSITION:

THERMAL DECOMPOSITION MAY RELEASE ACRID SMOKE AND IRRITATING FUMES. 
POLYMERIZATION :

HAZARDOUS POLYMERIZATION HAS NOT BEEN REPORTED TO OCCUR UNDER NORMAL TEMPERATURES AND PRESSURES.

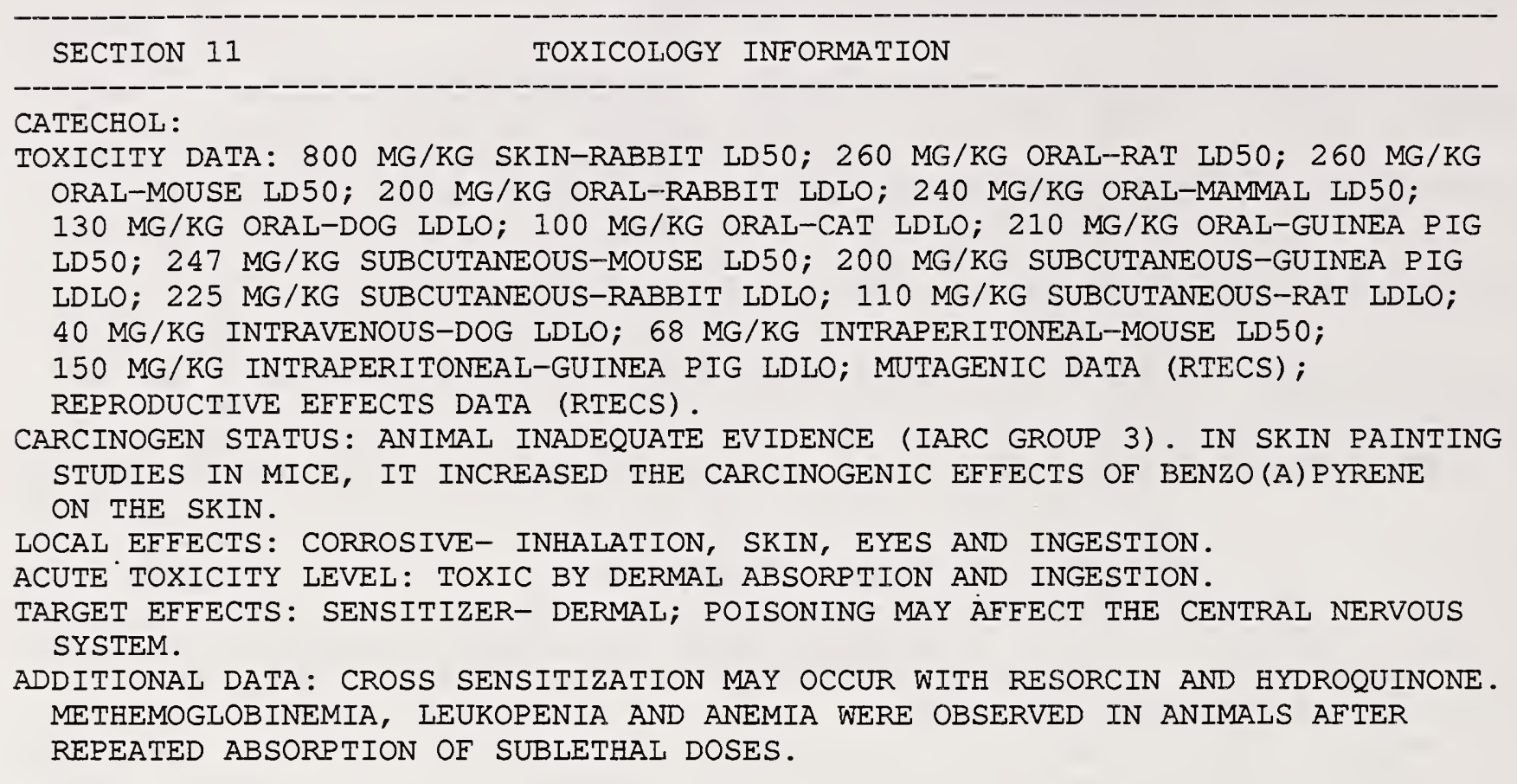

HEALTH EFFECTS

INHALATION :

CATECHOL:

CORROSIVE.

ACUTE EXPOSURE- INHALATION MAY CAUSE SEVERE IRRITATION OF THE RESPIRATORY TRACT, SORE THROAT, COUGHING, ABDOMINAL SPASM AND DIFFICULTY BREATHING. ABSORPTION OF SUFFICIENT AMOUNTS MAY RESULT IN SYSTEMIC EFFECTS AS DESCRIBED IN SKIN EXPOSURE. IRRITATION AND TREMORS WERE OBSERVED IN RATS EXPOSED TO CONCENTRATIONS OF 2 OR $2.8 \mathrm{GM} / \mathrm{M} 3 / 8$ HOURS; NO VISIBLE EFFECTS WERE OBSERVED FROM EXPOSURE TO $1.5 \mathrm{GM} / \mathrm{M} 3$.

CHRONIC EXPOSURE- NO DATA AVAILABLE.

SKIN CONTACT:

CATECHOL :

CORROSIVE/SENSITIZER/TOXIC.

ACUTE EXPOSURE- MAY CAUSE SEVERE IRRITATION WITH REDNESS, PAIN AND BURNS. SENSITIZATION REACTIONS MAY OCCUR IN PREVIOUSLY EXPOSED PERSONS. ABSORPTION OF SUFFICIENT AMOUNTS THROUGH THE SKIN MAY CAUSE PROFUSE SWEATING, INTENSE THRIST, NAUSEA AND VOMITING, DIARRHEA, CYANOSIS FROM METHEMOGLOBINEMIA, HYPERACTIVITY, STUPOR, BLOOD PRESSURE FALL, HYPERPNEA, ABDOMINAL PAIN, HEMOLYSIS, CONVULSIONS, COMA, AND PULMONARY EDEMA FOLLOWED BY PNEUMONIA. IF DEATH FROM RESPIRATORY FAILURE IS NOT IMMEDIATE, JAUNDICE AND OLIGURIA OR ANURIA MAY OCCUR.

CHRONIC EXPOSURE- REPEATED OR PROLONGED CONTACT MAY CAUSE DEPIGMENTATION, ECZEMATOUS DERMATITIS AND EFFECTS AS DESCRIBED IN ACUTE EXPOSURE. IN SKIN PAINTING STUDIES WITH MICE, CATECHOL INCREASED THE CARCINOGENIC EFFECTS OF 
OHSO 4360

BENZO (A) PYRENE ON THE SKIN.

EYE CONTACT:

CATECHOL :

CORROSIVE.

ACUTE EXPOSURE- MAY CAUSE SEVERE IRRITATION, REDNESS, PAIN, BLURRED VISION, SIOW HEALING BURNS, AND POSSIBLE PERMANENT IMPAIRMENT OF VISION.

CHRONIC EXPOSURE- DEPENDING UPON THE CONCENTRATION AND DURATION OF EXPOSURE, REPEATED OR PROLONGED CONTACT WITH CORROSIVE SUBSTANCE MAY RESULT IN CONJUNCTIVITIS OR EFFECTS AS IN ACUTE EXPOSURE.

INGESTION :

CATECHOL :

CORROSIVE/TOXIC.

ACUTE EXPOSURE- MAY CAUSE SEVERE IRRITATION, VOMITING, DIARRHEA, AND ABDOMINAL PAIN. SYSTEMIC EFFECTS SIMILAR TO THOSE DESCRIBED IN SKIN EXPOSURE MAY OCCUR. THE LETHAL DOSE REPORTED IN RATS WAS $260 \mathrm{MG} / \mathrm{KG}$.

CHRONIC EXPOSURE- IN RATS, CATECHOI INDUCED ADENOCARCINOMA AND ADENOMATOUS HYPERPIASIA IN THE PYLORIC REGION OF THE GLANDULAR STOMACH.

SECTION 12 ECOLOGICAL INEORMATION

ENVIRONMENTAL IMPACT RATING $(0-4)$ : NO DATA AVAILABLE

ACUTE AQUATIC TOXICITY: NO DATA AVAILABLE

DEGRADABILITY: NO DATA AVAILABLE

LOG BIOCONCENTRATION FACTOR (BCF): NO DATA AVAILABLE

LOG OCTANOL/WATER PARTITION COEFFICIENT: NO DATA AVAILABLE

SECTION 13

DISPOSAL INFORMATION

OBSERVE ALI FEDERAL, STATE AND LOCAL REGULATIONS WHEN DISPOSING OF THIS SUBSTANCE.

SECTION 14

TRANSPORTATION INFORMATION

NO CIAASSIFICATION CURRENTLY ASSIGNED

SECTION 15

REGULATORY INFORMATION

TSCA STATUS: Y

CERCLA SECTION 103 (40CFR302.4): N

SARA SECTION 302 (40CFR355.30): N

SARA SECTION 304 (40CFR355.40): N

SARA SECTION 313 (40CFR372.65):

OSHA PROCESS SAFETY (29CFR1910.119): N 
CALIFORNIA PROPOSITION 65:

SARA HAZARD CATEGORIES, SARA SECTIONS $311 / 312$ (40 CFR 370.21)

ACUTE HAZARD:

CHRONIC HAZARD:

$Y$

FIRE HAZARD:

REACTIVITY HAZARD:

SUDDEN RELEASE HAZARD:

$Y$

$\mathrm{N}$

$\mathrm{N}$

$\mathrm{N}$

SECTION 16

OTHER

COPYRIGHT 1993 OCCUPATIONAL HEALTH SERVICES, INC.. ALL RIGHTS RESERVED.

Licensed to: National Institute of Standards and Technology

To make unlimited paper copies for internal distribution and use only. Permission received 11/22/93 from Richard Cohen, V.P. at OHS, Inc. to

distribute this MSDS to the MOSIS community.

Permission received 1/21/94 from Richard Cohen, V.P. at OHS, Inc. to include this MSDS in a NIST Internal Report.

The above MSDS (Material Safety Data Sheet) was prepared by Occupational Health Services, Inc. from data received from various sources. OHS, Inc. did not perform the tests, therefore this MSDS is meant solely as a guide and the National Institute of Standards and Technology, the Information Sciences Institute, the George Washington University, and Occupational Health Services, Inc. are not liable under any circumstances for any accidents or inadequate information associated with the substance for which this MSDS was written. 
APPENDIX C. THE MSDS FOR THE SUBSTANCE PYRAZINE

OHS 68746

SECTION 1

CHEMICAL PRODUCTS \& COMPANY IDENTIFICATION

OCCUPATIONAL HEALTH SERVICES, INC.

FOR EMERGENCY SOURCE INFORMATION

11 WEST 42ND STREET, 12TH FLOOR

CONTACT: 1-615-366-2000

NEW YORK, NEW YORK 10036

1-800-445-MSDS (1-800-445-6737) OR

$1-212-789-3535$

CAS NUMBER: 290-37-9

RTECS NUMBER: UQ2015000

SUBSTANCE：PYRAZINE

TRADE NAMES/SYNONYMS:

1,4-DIAZABENZENE; P-DIAZINE; 1,4-DIAZINE; PARADIAZINE; PIAZINE; C4H4N2;

OHS 68746

CHEMICAI FAMILY:

Pyrazine

CREATION DATE: 12/21/92 REVISION DATE: 03/24/93

\section{SECTION 2 COMPOSITION/INFORMATION ON INGREDIENTS}

COMPONENT : PYRAZINE

CAS NUMBER: 290-37-9

PERCENTAGE : 100.0

OTHER CONTAMINANTS: NONE.

SECTION 3

HAZARDS IDENTIFICATION

CERCLA RATINGS (SCALE 0-3): HEALTH=2 FIRE=2 REACTIVITY=0 PERSISTENCE=0

NFPA RATINGS (SCALE 0-4): HEALTH=U FIRE=2 REACTIVITY=0

EMERGENCY OVERVIEW:

May form flammable or explosive dust-air mixtures.

Keep away from all ignition sources. Avoid dispersion of dust.

POTENTIAL HEALTH EFFECTS:

INHALATION :

SHORT TERM EFFECTS: May cause irritation.

LONG TERM EFFECTS: No information is available.

SKIN CONTACT:

SHORT TERM EFFECTS: May cause irritation.

LONG TERM EFFECTS: No information is available.

EYE CONTACT:

SHORT TERM EFFECTS: May cause irritation.

LONG TERM EFFECTS: No information is available. 
INGESTION :

SHORT TERM EFFECTS: No information is available.

LONG TERM EFFECTS: No information is available.

CARCINOGEN STATUS:

OSHA: $N$

NTP : N

IARC: $N$

SECTION 4

FIRST AID MEASURES

INHALATION :

FIRST AID- Remove from exposure area to fresh aix immediately. If breathing has stopped, perform artificial respiration. Keep person warm and at rest. Treat symptomatically and supportively. Get medical attention immediately.

SKIN CONTACT:

FIRST AID- Remove contaminated clothing and shoes immediately. Wash affected area with soap or mild detergent and large amounts of water until no evidence of chemical remains (approximately 15-20 minutes). Get medical attention immediately.

EYE CONTACT:

FIRST AID- Wash eyes immediately with large amounts of water or normal saline, occasionally lifting upper and lower lids, until no evidence of chemical remains (approximately 15-20 minutes). Get medical attention immediately.

INGESTION :

FIRST AID- Treat symptomatically and supportively. Get medical attention immediately. If vomiting occurs, keep head lower than hips to prevent aspiration.

NOTE TO PHYSICIAN

ANTIDOTE:

No specific antidote. Treat symptomatically and supportively.

SECTION 5

FIRE FIGHTING MEASURES

FIRE AND EXPLOSION HAZARD:

Moderate fire hazard when exposed to heat or flame.

Dust-air mixtures may ignite or explode.

EXTINGUISHING MEDIA:

Dry chemical, carbon dioxide, water spray or regular foam

(1990 Emergency Response Guidebook, DOT P 5800.5).

For larger fires, use water spray, fog or regular foam

(1990 Emergency Response Guidebook, DOT P 5800.5).

FIREFIGHTING : 
Move container from fire area if you can do it without risk. Do not scatter spilled material with high-pressure water streams. Dike fire-control water for later disposal (1990 Emergency Response Guidebook, DOT P 5800.5, Guide Page 31).

Use agents suitable for type of surrounding fire. Avoid breathing hazardous vapors, keep upwind.

FIAASH POINT: $132 \mathrm{~F}(56 \mathrm{C})$

HAZARDOUS COMBUSTION PRODUCTS:

Thermal decomposition products may include toxic oxides of carbon and nitrogen.

\section{SECTION 6}

ACCIDENTAL RELEASE MEASURES

OCCUPATIONAL SPILL:

Sweep up and place in suitable clean, dry containers for reclamation or later disposal. Do not flush spilled material into sewer. Keep unnecessary people away.

\section{SECTION 7}

HANDIING AND STORAGE

Observe all federal, state and local regulations when storing this substance.

Store in a cool, dry place; keep container tightly closed when not in use.

Store away from incompatible substances.

SECTION 8

EXPOSURE CONTROLS/PERSONAI PROTECTION

EXPOSURE LIMITS:

No occupational exposure limits established by OSHA, ACGIH, or NIOSH.

VENTILATION:

Provide local exhaust ventilation. Ventilation equipment must be explosion proof.

EYE PROTECTION :

Employee must wear splash-proof or dust-resistant safety goggles to prevent eye contact with this substance.

Emergency eye wash: Where there is any possibility that an employee's eyes may be exposed to this substance, the employer should provide an eye wash fountain within the immediate work area for emergency use.

CLOTHING :

Employee must wear appropriate protective (impervious) clothing and equipment to prevent repeated or prolonged skin contact with this substance.

GLOVES : 
Employee must wear appropriate protective gloves to prevent contact with this substance.

RESPIRATOR:

The following respirators are recommended based on information found in the physical data, toxicity and health effects sections. They are ranked in order from minimum to maximum respiratory protection.

The specific respirator selected must be based on contamination levels found in the work place, must be based on the specific operation, must not exceed the working limits of the respirator and must be jointly approved by the National Institute for Occupational Safety and Health and the Mine Safety and Health Administration (NIOSH-MSHA).

Any dust and mist respirator.

Any air-purifying respirator with a high-efficiency particulate filter.

Any powered air-purifying respirator with a dust and mist filter.

Any powered air-purifying respirator with a high-efficiency particulate filter.

Any type ' $C$ ' supplied-air respirator operated in the pressure-demand or other positive pressure or continuous-flow mode.

Any self-contained breathing apparatus.

FOR FIREFIGHTING AND OTHER IMMEDIATELY DANGEROUS TO LIFE OR HEALTH CONDITIONS:

Any self-contained breathing apparatus that has a full facepiece and is operated in a pressure-demand or other positive-pressure mode.

Any supplied-air respirator that has a full facepiece and is operated in a pressure-demand or other positive-pressure mode in combination with an auxiliary self-contained breathing apparatus operated in pressure-demand or other positive-pressure mode.

SECTION 9 PHYSICAL AND CHEMICAL PROPERTIES

DESCRIPTION: Crystals or wax-like solid with a strong pyridine odor. MOLECULAR WEIGHT: 80.09

MOLECULAR FORMULA: N-C-H-C-H-N-C-H-C-H

BOILING POINT: 239-244 F (115-118 C)

MELTING POINT: $127-133 \mathrm{~F}(53-56 \mathrm{C})$

SPECIFIC GRAVITY: 1.031

WATER SOLUBILITY: soluble

SOLVENT SOLUBILITY: Soluble in alcohol and ether.

REFRACTIVE INDEX: 1.4953 
REACTIVITY:

Stable under normal temperatures and pressures.

CONDITIONS TO AVOID:

May burn but does not ignite readily. Avoid contact with strong oxidizers, excessive heat, sparks, or open flame.

INCOMPATIBILITIES:

PYRAZINE :

ACIDS (STRONG): Incompatible.

OXIDIZERS (STRONG): Fire and explosion hazard.

HAZARDOUS DECOMPOSITION:

Thermal decomposition products may include toxic oxides of carbon and nitrogen.

POLYMERIZATION :

Hazardous polymerization has not been reported to occur under normal temperatures and pressures.

SECTION 11

TOXICOLOGY INEORMATION

PYRAZINE:

TOXICITY DATA: $2730 \mathrm{mg} / \mathrm{kg}$ intraperitoneal-mouse LD50; mutagenic data (RTECS). CARCINOGEN STATUS: NONE.

ACUTE TOXICITY LEVEL: Insufficient data.

TARGET EFFECTS: No data available.

HEALTH EFFECTS

INHALATION :

PYRAZINE :

ACUTE EXPOSURE- May cause irritation.

CHRONIC EXPOSURE- No data available.

SKIN CONTACT:

PYRAZINE :

ACUTE EXPOSURE- May cause irritation.

CHRONIC EXPOSURE- No data available.

EYE CONTACT:

PYRAZINE :

ACUTE EXPOSURE- May cause irritation.

CHRONIC EXPOSURE- No data available.

INGESTION :

PYRAZINE :

ACUTE EXPOSURE- No data available.

CHRONIC EXPOSURE- No data available. 
OHS68746

ENVIRONMENTAL IMPACT RATING (0-4): no data available

ACUTE AQUATIC TOXICITY: no data available

DEGRADABILITY: no data available

LOG BIOCONCENTRATION FACTOR (BCF): no data available

LOG OCTANOL/WATER PARTITION COEFFICIENT: no data available

SECTION 13
Observe all federal, state and local regulations when disposing of this
substance.
SECTION 14
No classification currently assigned
SECTION 15
REGULATORY INFORMATION

TSCA STATUS: Y

CERCLA SECTION 103 (40CFR302.4): N

SARA SECTION 302 (40CFR355.30): N

SARA SECTION 304 (40CFR355.40): N

SARA SECTION 313 (40CFR372.65): N

OSHA PROCESS SAFETY (29CER1910.119): N

CALIFORNIA PROPOSITION 65: N

SARA HAZARD CATEGORIES, SARA SECTIONS 311/312 (40 CFR 370.21)

ACUTE HAZARD:

CHRONIC HAZARD:

FIRE HAZARD:

REACTIVITY HAZARD: $\quad \mathrm{N}$

SUDDEN RELEASE HAZARD: N

SECTION 16

OTHER

COPYRIGHT 1993 OCCUPATIONAL HEALTH SERVICES, INC.. ALI RIGHTS RESERVED.

Licensed to: National Institute of Standards \& Technology R. I. C. To make unlimited paper copies for internal distribution and use only. Permission received 2/14/94 from Richard Cohen, V.P. at OHS, Inc. to distribute this MSDS to the MOSIS community and to include this MSDS in a NIST Internal Report.

The above MSDS (Material Safety Data Sheet) was prepared by Occupational Health Services, Inc. from data received from various sources. OHS, Inc. did not perform the tests, therefore this MSDS is meant solely as a guide and the National Institute of Standards and Technology, the Information Sciences Institute, the George Washington University, and Occupational Health Services, Inc., are not liable under any circumstances for any accidents or inadequate information associated with the substance for which this MSDS was written. 

